\title{
POTENTIA DEI ABSOLUTA \\ ET POTENTIA DEI ORDINATA U ORYGENESA? NOWA PRÓBA WYJAŚNIENIA KONTROWERSYJNYCH FRAGMENTÓW DE PRINCIPIIS
}

W dziełach Orygenesa znajdujemy cztery wypowiedzi, na podstawie których wielu historyków idei wyciaga wniosek, jakoby myśliciel z Aleksandrii odziedziczył po filozofach greckich negatywne rozumienie nieskończoności, gdyż uznał, że moc Boga jest skończona․ Trzy z nich pochodzą z działa $O$ zasadach $^{2}$, a jedna z Komentarza do Ewangelii wedtug św. Mateusza ${ }^{3}$. We wcześniejszych moich badaniach ${ }^{4}$ wykazałem jednakże, że we wszystkich tych fragmentach jest wprawdzie mowa o skończoności świata i skończonej liczbie stworzeń, które stworzył Bóg, lecz nie zawierają one explicite tezy o skończonej mocy Boga. Ponadto, w innych miejscach swoich dzieł Adamancjusz posługuje się nawet terminem ö́rııрos („nieskończony”) w odniesieniu do Boga i Jego wiedzy ${ }^{5}$, czego nie dostrzega wielu badaczy jego myśli. Jednakże nie tylko w oparciu o same użycie tego terminu, który w filozofii greckiej posiadał przeważnie konotacje negatywne, możemy wnioskować, że myśliciel z Aleksandrii wierzył w Boga nieskończonego. W dziełach zachowanych w języku

${ }^{*}$ Dr Damian Mrugalski OP - wykładowca patrologii, historii filozofii starożytnej i języka greckiego w Kolegium Filozoficzno-Teologicznym Polskiej Prowincji Dominikanów w Krakowie; e-mail: mnichop@gmail.com.

${ }^{1}$ Por. H. Crouzel - M. Simonetti, nota 2, w: Origène, Traité des principes, t. 2: Commentaire et fragments, SCh 253, Paris 1978, 213; M. Simonetti, Dio (Padre), w: Origene. Dizionario. La cultura, il pensiero, le opere, ed. A. Monaci Castagno, Roma 2000, 120; C. Moreschini, Storia della filosofia patristica, Brescia 2005, 136; M. Szram, Orygenes, PEF VII 864.

${ }^{2}$ Por. Origenes, De principiis II 9, 1; III 5, 2; IV 4, 8.

${ }^{3}$ Por. tenże, Commentarius in Matthaeum XIII 1.

${ }^{4}$ Zob. D. Mrugalski, Nieskończoność Boga u Orygenesa: Przyczyna wielkiego nieporozumienia, VoxP 37 (2017) t. 67, 437-475; tenże, Nieskończoność Boga u Nowacjana: Prawdopodobne źródta greckie, „Przegląd Tomistyczny” 23 (2017) 147-181, gdzie dowodzę między innymi, że wypowiedź Nowacjana (De Trinitate 4, 8-9) o tym, że nie mogą istnieć dwie nieskończoności, rzuca również nowe światło na stwierdzenia Orygenesa (De principiis II 9, 1; IV 4, 8; III 5, 2) o skończoności stworzenia. Nieskończoność może być tylko jedna i jest nią Bóg, a nie stworzenie. Jest prawdopodobne, że inspiracją do sformułowania takiej tezy mogły być dla Nowacjana wskazane wyżej wypowiedzi Orygenesa.

${ }^{5}$ Por. Origenes, Contra Celsum III 77; Philocalia XXIII 20; De oratione XXVII 16. 
greckim, ale i w tłumaczeniach, które dotarły do nas w języku łacińskim, dostrzegalna jest kontynuacja i rozwój doktryny aleksandryjskich poprzedników Orygenesa - Filona i Klemensa - o nieskończenie dobrym, wszechmocnym i wszechwiedzącym Intelekcie, jakim jest Bóg. Widać ją wyraźnie w szeregu metafor i sformułowań filozoficznych wskazujących na podstawową różnicę, jaka istnieje między Absolutem a Jego stworzeniem: nieskończoność istoty, wiedzy i mocy pierwszego wobec skończoności, co do liczby i miary drugiego ${ }^{6}$.

W związku z powyższym, we wspomnianym wyżej artykule postawiłem tezę, że przekazane przez Justyniana dwa fragmenty dzieła $O$ zasadach (II 9, 1 oraz IV 4, 8), w których explicite pojawia się teza o skończonej mocy Boga, nie wyrażają opinii Orygenesa, lecz cesarza, który nie zrozumiał skomplikowanego wykładu i rozróżnień dokonywanych przez myśliciela z Aleksandrii. Tym samym przyznałem rację Rufinowi, który w swym łacińskim tłumaczeniu dzieła De principiis wiernie oddał intuicję Adamancjusza ${ }^{7}$.

W niniejszym tekście, choć nie odcinam się od tego, co wcześniej dowiodłem, postaram się przebyć inną drogę. Mimo że - jak zauważa Stanisław Kalinkowski - fragmenty Justyniana z Listu do Manesa są zwykle przedstawiane tendencyjnie ${ }^{8}$, przyjmę założenie, że cesarz wiernie oddał wypowiedź Orygenesa oraz spróbuję zrozumieć, co może znaczyć stwierdzenie, że „moc Boża jest ograniczona, i nie należy usuwać jej granic pod pozorem oddawania Bogu czci" ". Być może mówienie o ograniczonej mocy Boga działającej w stworzeniu, a więc o mocy Boga ad extra, nie musi zaprzeczać tezie o nieskończonej mocy Boga in se. Tego typu rozróżnienia znajdujemy bowiem w tradycji aleksandryjskiej poprzedzającej Orygenesa, ale także w jego własnych dziełach. Być może Orygenes jest po prostu prekursorem doktryny postulującej istnienie potentia Dei absoluta oraz potenta Dei ordinata, na temat której będą się toczyły zagorzałe dyskusje w średniowieczu ${ }^{10}$ ?

${ }^{6}$ Por. D. Mrugalski, Metamorfozy platońskiej ,, metafory stońca” (Respublica 509b) whetero- $i$ ortodoksyjnej teologii (I-III w.): Gnostycyzm, Klemens z Aleksandrii i Orygenes, VoxP 37 (2017) t. 68, 21-58, gdzie ukazuję podobieństwa między metaforami i formułami filozoficznymi, którymi w odniesieniu do Boga posługiwał się Orygenes, i tymi, którymi posługiwali się jego poprzednicy. Niewątpliwie Platońska metafora słońca, zmodyfikowana przez zhellenizowanych Żydów i chrześcijan, również wskazuje na nieskończoność Bożej mocy. Słońce symbolizuje w niej bowiem transcendentne Dobro, które w swym udzielaniu się nie zna kresu, jego promienie zaś niewyczerpaną Bożą moc.

${ }^{7}$ Por. tenże, Nieskończoność Boga u Orygenesa, s. 471-473.

${ }^{8}$ Por. S. Kalinkowski, Pneumatologia Orygenesa, CT 53 (1983) 47.

${ }^{9}$ Justinianus Imperator, Epistula ad Mennam Constantinopolitanum, Mansi IX $489=$ Origenes, De principiis II 9, 1, SCh 253, 211, tłum. S. Kalinkowski: Orygenes, O zasadach, ŹMT 1, Kraków 1996, 205.

${ }^{10}$ Szerzej na temat tej średniowiecznej dystynkcji oraz jej możliwych źródeł patrystycznych zob. W.J. Courtenay, Capacity and Volition: A History of the Distinction of Absolute and Ordained Power, Bergamo 1990; G. Van den Brink, Almighty God: A Study of the Doctrine of Divine Omnipotence, Kampen 1993, 43-92; M. Paluch, Jak zdefiniować wszechmoc? Wprowadzenie do Kwestii I, w: Tomasz z Akwinu, Kwestie dyskutowane o mocy Boga, t. 1, red. M. Olszewski - M. Paluch, Kęty 
1. Filon Aleksandryjski o dwóch rodzajach różnych mocy Boga. Filon Aleksandryjski, którego alegoryczną egzegezą Orygenes był zainspirowany, szeroko rozwija doktrynę Bożych mocy. Pochodzenie tej wieloaspektowej

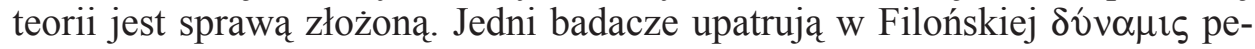
wien dynamiczny aspekt Platońskich idei, inni, wskazując na źródła stoickie, dostrzegają w niej moc Logosu przenikającego kosmos, jeszcze inni doszukują się wątków Arystotelesowskich, a nawet elementów mitologii egipskiej czy irańskiej ${ }^{11}$. Niezależnie od tego, które ze źródeł myśli Aleksandryjczyka uznamy za uprzywilejowane, koncept Bożych mocy, którym posługuje się w alegorycznym komentowaniu tekstu biblijnego wykorzystywany jest przez niego w celu podkreślenia Bożej transcendencji względem świata. Tak więc, nie Bóg w swojej istocie, lecz Jego moce obecne są i działają w świecie ${ }^{12}$. Ze względu jednak na nieskończoność Bożej natury oraz kruchość i skończoność stworzeń Filon dochodzi do wniosku, że Bóg stwarzając świat i udzielając mu swoich dobrodziejstw, nie mógł posłużyć się całą swoją mocą, którą posiada. Ta bowiem, podobnie jak Boża istota jest nieskończona ${ }^{13}$. Dlatego też Aleksandryjczyk dokonuje rozróżnienia na moce czyste i zmieszane:

„Wobec samego siebie Bóg posługuje się mocami czystymi (ó yò

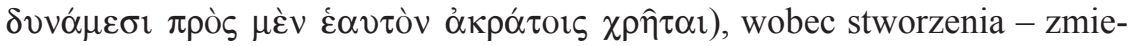

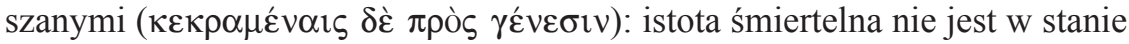
ich przyjąć w ich czystej formie. Przecież zdajesz sobie sprawę, że nie możesz patrzeć na czysty żar słońca: wzrok bowiem, zanim się wzniesie, aby go przyjać, zgaśnie oślepiony lśniącym blaskiem promieni. Wszak i słońce jest dziełem Boga, jest cząstką nieba, skondensowanym eterem. Czy więc uważasz, że możesz pojąć w czystej postaci owe niezrodzone moce, które otaczają Boga i wydają z siebie najjaśniejszą światłość?"14.

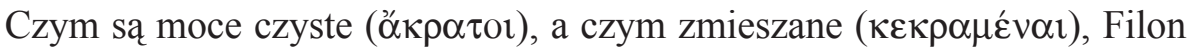
wyjaśnia $\mathrm{w}$ dalszej części tekstu, $\mathrm{z}$ którego pochodzi zacytowany fragment.

\footnotetext{
- Warszawa 2008, 19-52; tenże, Oswajanie wszechmocy. Droga do Tomaszowej interpretacji wszechmocy, „Przegląd Tomistyczny” 15 (2009) 263-279; M. Pepliński, Problematyka wszechmocy Boga - rzeczy nowe i stare, „Filo-Sofija” 30 (2015) 11-44; E. Jung, Świat możliwy versus świat realny w koncepcjach średniowiecznych, czyli o boskiej mocy absoluta i ordinata, „Filo-Sofija” 30 (2015) 67-80.

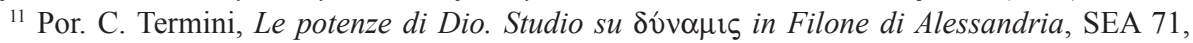
Roma 2000, 10-18.

${ }^{12}$ Por. Philo Alexandrinus, De posteritate Caini 20; tenże, De Cherubim 27-30; tenże, De confusione linguarum 136-137 i 175.

${ }^{13}$ Por. tenże, De opificio mundi 23; tenże, Quis rerum divinarum heres sit 31-33; tenże, Quod Deus sit immutabilis 80-81; tenże, Legum allegoriae I 34. Zob. także Mrugalski, Nieskończoność Boga u Orygenesa, s. 442-450; B.S. Decharneux, Divine Powers in Philo of Alexandria's „De opificio mundi", w: Divine Powers in Late Antiquity, ed. A. Marmodoro - I.F. Viltanioti, Oxford 2017, 131-133.

${ }^{14}$ Philo Alexandrinus, Quod Deus sit immutabilis 77-78, ed. G.P. Goold, LCL 247, Cambridge London 1988, 48, thum. S. Kalinkowski: Filon Aleksandryjski, Pisma, t. 2, Kraków, 1994, 33 (tłum. nieznacznie zmienione).
} 
Rozwijając metaforę słońca i promieni zauważa, że żar, który jest w słońcu, choć jest źródłem światła i ciepła, które dociera do ziemi, nie jest na niej obecny w czystej postaci. Promienie z niego pochodzące mieszają się bowiem z zimnym powietrzem i w ten sposób nie wyrządzają szkody stworzeniom. Są to jednak te same promienie, których źródło ciepła i blasku znajduje się w słońcu ${ }^{15}$. Tak wyjaśniona metafora nastręcza jednak pewnych trudności interpretacyjnych. $\mathrm{Z}$ czym w takim razie mieszają się Boskie moce? I czy jest to w ogóle możliwe skoro, jak podkreśla w innych miejscach Filon, są one natury inteligibilnej

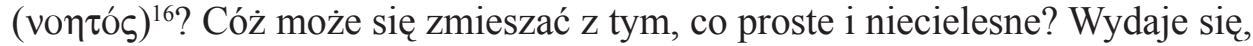

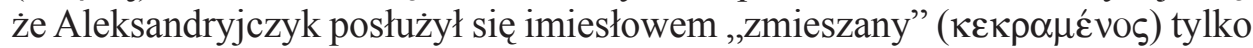
dlatego, że jego wywód stanowi alegoryczną interpretację fragmentu Psalmu 74, w którym czytamy: „W ręku Pana jest kielich pełen mieszaniny czystego wina"17. Zwyczajem starożytnych było, aby mieszać czyste wino z wodac w celu złagodzenia jego mocy. W metaforze biblijnej - co nie umyka uwadze Filona - zawarty jest jednak pewien paradoks: Bóg dzierży kielich wypełniony

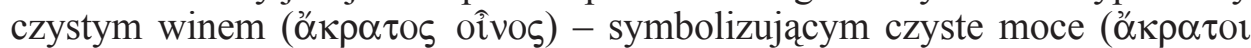

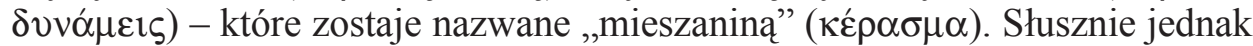
jest tu mowa o mieszaninie - zauważa Aleksandryjczyk - gdyż stworzenie, które ma pić $\mathrm{z}$ tego Bożego kielicha, nie jest w stanie przyjąć w czystej postaci całej mocy Boga (podobnie, jak żołądek niektórych ludzi nie toleruje mocnego, to znaczy niezłagodzonego wodą wina). Użyty w tym kontekście imiesłów $\kappa \varepsilon-$

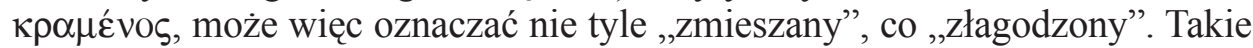
znaczenie sugeruje również konkluzja Filonowej argumentacji:

„Demiurg zatem rozumiejąc swą wyższość nad wszystkim, co doskonałe, oraz znając przyrodzoną słabość istot stworzonych, choć one mają wysokie mniemanie o sobie, nie chce wyświadczać im dobrodziejstw ani ich karać tak, jakby mógł, lecz dostosowuje swe działanie do możliwości, którą, jak widzi, dysponują ludzie doznający dobrodziejstwa i kary"18.

Z powyższego cytatu wynika więc, że Bóg, którego Aleksandryjczyk

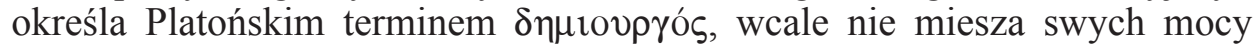
z powietrzem, czy innymi elementami świata fizycznego, lecz je łagodzi. Łagodzi więc zarówno dobrodziejstwa, jak i kary, które wymierza za pośred-

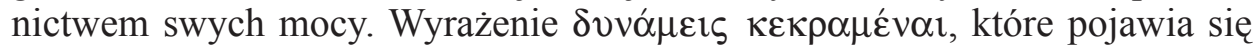
w toku alegorycznej interpretacji Ps 74, 9, wskazuje zatem na ograniczona, złagodzoną lub też odpowiednio wymierzoną moc Boga, czyli taką jaką jest w stanie przyjąć Jego stworzenie. Stwierdzenie to nie oznacza, że moc Boga

${ }^{15}$ Por. tamże 78-79.

${ }^{16}$ Por. tenże, De opificio mundi 20-25; tenże, De Cherubim 97; tenże, De confusione linguarum 171-172; tenże, De specialibus legibus I 46.

${ }^{17}$ Ps 74, 9, w wersji LXX. Por. Philo Alexandrinus, Quod Deus sit immutabilis 77, LCL 247,

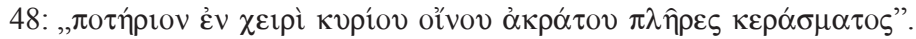

${ }^{18}$ Philo Alexandrinus, Quod Deus sit immutabilis 80, LCL 247, 50, thum. Kalinkowski, s. 34. 
jest skończona w swej istocie, lecz, że nieskończonej mocy Boga nie są w stanie przyjąć skończone stworzenia. Na tym właśnie polega różnica między tym co skończone, a tym co nieskończone. To pierwsze z natury nie jest w stanie przyjąć i ogarnąć tego drugiego.

Podobną intuicję znajdujemy przy okazji alegorycznej interpretacji spotkania Abrahama z trzema mężami pod dębami Mamre (por. Rdz 18, 1-6):

„Bóg przybywszy w otoczeniu swych dwóch najwyższych mocy, Władzy i Dobroci, jeden będąc pośrodku nich, wzbudził trzy wyobrażenia ( $\tau \rho \imath \tau \tau \grave{\varsigma} \varsigma$ $\varphi \alpha \nu \tau \alpha \sigma i \alpha \varsigma)$ w duszy zdolnej do widzenia. Każde z nich, choć w żaden sposób nie otrzymało określonej miary - Bóg bowiem jest nieskończony i nie-

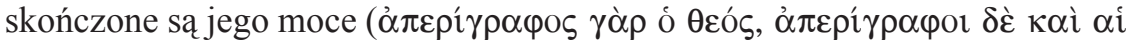

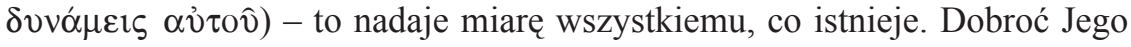
jest więc miarą rzeczy dobrych, zaś Władza jest miarą rzeczy jej poddanych. Natomiast sam Władca jest miarą wszelkich bytów cielesnych i niecielesnych. Za Jego przyczyną moce przyjmują funkcję norm i reguł oraz odmierzają rzeczy, które są im poddane"19.

Tekst z Rdz 18, który opisuje tajemniczą gościnę trzech mężów w domu Abrahama będzie interpretowany przez Ojców Kościoła jako argument skrypturystyczny na rzecz Trójcy Świętej objawiającej się także w czasach Starego Testamentu $^{20}$. Żyd z Aleksandrii z oczywistych względów nie mówi przy tej okazji o Ojcu, Synu i Duchu Świętym, lecz o Bogu i dwóch jego najwyższych

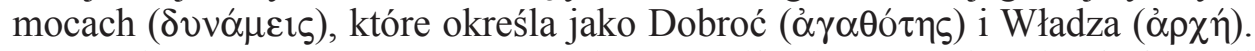
Interesujące jest $\mathrm{w}$ powyższym cytacie to, że Filon interpretuje epizod $\mathrm{z}$ historii życia Abrahama jako wizję, która miała miejsce jedynie w intelekcie patriarchy. Bóg bowiem, jak stwierdza, wytworzył trzy obrazy w duszy widzącego

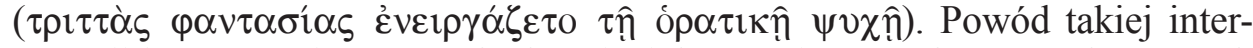
pretacji jest oczywisty: Bóg, będąc niecielesny, nie może być w żaden sposób widziany oczyma ciała. Mało tego, wyobrażenie, które powstało w intelekcie Abrahama nie było, i nie mogło być według Aleksandryjczyka, ściśle określone (czy odmierzone), gdyż Bóg, będąc nieskończony nie podlega żadnym miarom czy jakimkolwiek ograniczeniom. Nieskończone są również Jego moce. Po tym stwierdzeniu, które dotyczy istoty i mocy Boga in se, Filon przechodzi do opisu działania Boga ad extra. Tak więc w świecie Bóg działa za sprawą swych mocy, które nadają miarę ( $\mu$ ć $\tau \rho o v)$ wszystkiemu, co istnieje. Owa miara to nie tylko formy ${ }^{21}$, które otrzymują byty cielesne w momencie stworzenia, ale

${ }^{19}$ Tenże, De sacrificiis 59, ed. G.P. Goold, LCL 227, 138, Cambridge - London 1994, thum. własne.

${ }^{20}$ Początkowo patrystyczna interpretacja Rdz 18 (zwłaszcza u apologetów, ale i u Orygenesa) była związana jeszcze $\mathrm{z}$ angelologia, niekiedy z chrystologią angelomorficzną. $\mathrm{Z}$ czasem jednak Ojcowie Kościoła zaczęli dostrzegać w wizycie trzech mężów pod dębami Mamre mysterium Trinitatis. Zob. B.G. Bucur, The Early Christian Reception of Genesis 18: From Theophany to Trinitarian Symbolism, JECS 23 (2015) 245-272.

${ }^{21}$ Por. Philo Alexandrinus, De specialibus legibus I 329. 
i wszelkiego rodzaju prawa oraz reguły, które panują w świecie stworzonym. Same zaś moce, choć są miarami wszystkiego, w swej stwórczej i kierowniczej funkcji jaką pełnią, nie przekraczają miary, którą wyznaczył im Bóg - ostateczna „miara wszelkich bytów cielesnych i niecielesnych”. Miara nałożona przez Boga na moce dotyczy jednak jedynie ich aktywności w świecie, ze względu na ograniczenia tego ostatniego. W Bogu, jak to stwierdził wcześniej Aleksandryjczyk, moce nie posiadają żadnej miary (są $\alpha \pi \varepsilon \rho i ́ \gamma \rho \alpha \varphi o l)$, tak jak On sam

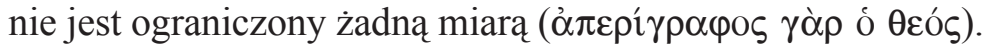

$\mathrm{Z}$ przytoczonych $\mathrm{w}$ tym paragrafie tekstów jasno wynika, że Filon wyróżnia dwa aspekty mocy Boga. Czym innym jest absolutna moc Boża, która istnieje w Bogu, a czym innym moc Boża objawiająca się w świecie. Ta druga oznacza działanie Boga dostosowane do możliwości, jakimi dysponuje przyjmujące je stworzenie. Można o niej powiedzieć, że jest skończona, a może lepiej, że jest w odpowiedni sposób wymierzona lub złagodzona. I choć Filon często mówi o mocach (w liczbie mnogiej), to warto zauważyć, że również Logos jest według niego mocą. Jest to moc szczególna, gdyż zawiera w sobie i jednoczy wszystkie pozostałe moce. To dzięki Niemu Bóg jest obecny w świecie i rządzi nim udzielając swych wielorakich łask i darów. Czyni to jednak zawsze w sposób odpowiednio wymierzony, czyli dostosowany do możliwości, jakimi dysponuje skończone stworzenie ${ }^{22}$.

2. Orygenes o dwóch aspektach jednej mocy Boga. Orygenes, zgodnie ze słowami Pawła (por. 1Kor 1, 24) uważa, że Mocą i Mądrością Boga ( $\theta \varepsilon \circ \hat{v}$

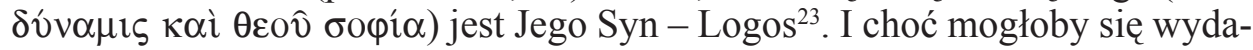
wać, że poprzez to stwierdzenie chrześcijański myśliciel odcina się od doktryny Żyda z Aleksandrii dotyczącej Bożych mocy, jednak w rzeczywistości wykorzystuje ją na swój sposób. Oto bowiem różne sposoby Bożej aktywności

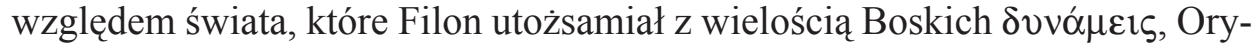
genes szeroko omawia w swej teorii dotyczącej દ̇đívoı $\alpha$, a więc rozlicznych tytułów Syna Bożego ${ }^{24}$. Z każdym z tych tytułów związane są pewne dobra, których Syn udziela światu, a właściwie, którymi jest On sam ${ }^{25}$. Stworzenia natomiast w mniejszym lub większym stopniu w nich uczestniczą:

${ }^{22}$ Por. tenże, De Cerubim 27; tenże, De opificio mundi 20-24; tenże, De Plantatione 8-10; tenże, De fuga et inventione 101-103; tenże, De migratione Abrahami 6; tenże, Quis rerum divinarum heres sit 205-206.

${ }^{23}$ Por. Origenes, De principiis I 2, 1; tenże, Commentarius in Joannem I 22, 140; I 34, 248.

${ }^{24}$ Warto tu również zauważyć, że u Orygenesa znajdujemy pewną reminiscencję Filońskiej doktryny wielości mocy, choć identyfikowane są one z pewną hierarchią istot anielskich. Zob. Origenes, Commentarius in Joannem I 39, 291. Por. M. Edwards, The Power of God in Some Early Christian Texts, w: Divine Powers in Late Antiquity, s. 170-173. Na temat źródeł koncepcji mocy Boga u Orygenesa zob. także I.L.E. Ramelli, Divine Power in Origen of Alexandria: Sources and Aftermath, w: Divine Powers in Late Antiquity, s. 177-198.

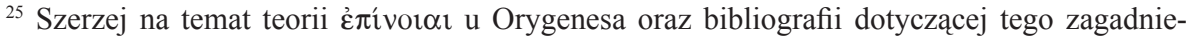
nia zob. M. Szram, Chrystus - Mądrość Boża wedtug Orygenesa, Lublin 1997, 63-76; D. Pazzini, 
„I niechaj się nikt nie dziwi naszemu uznaniu faktu, iż Jezus jest głoszony przy użyciu określenia występującego w liczbie mnogiej «dobra». Jeśli bowiem pojmiemy, do jakich spraw odnoszą się określenia dotyczące Syna Bożego, zrozumiemy też, dlaczego Jezus, którego głoszą ludzie «o pięknych nogach» (por. Rz 10, 15), jest kojarzony z licznymi dobrami. Jednym dobrem jest życie, i właśnie Jezus jest życiem. Drugie dobro to «światłość świata» (por. J 8, 12), która jest prawdziwą światłością, światłością ludzi, a przecież stwierdzono, że Syn Boży jest tym wszystkim. Obok życia i światłości kolej-

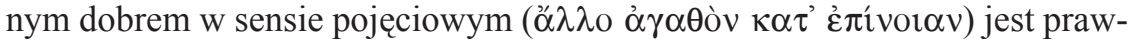
da, a czwartym droga, która do prawdy prowadzi. Zbawiciel nasz uczy, że On właśnie jest tym wszystkim, powiada bowiem: «Ja jestem drogą, prawdą i życiem» $(\mathrm{J} 14,6)^{\prime 2}$.

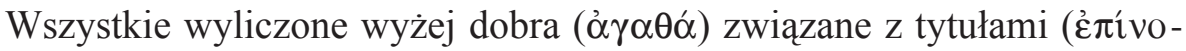

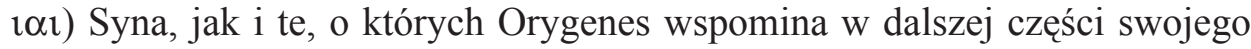
wywodu, stanowią w Chrystusie jedność. Ten bowiem jest jedną hipostazą i podobnie jak Ojciec - gdy chodzi o Jego Boską naturę - jest prosty i niezłożony $^{27}$. Człowiek natomiast jest w stanie - choć tylko i wyłącznie pojęciowo - wyodrębniać wieloaspektową aktywność czy różnorodność funkcji, jakie przyjmuje osoba Syna Bożego ${ }^{28}$. Tym jednak, co w tej Orygeniańskiej doktrynie o ع́đívol $\alpha$ jest istotne dla naszego tematu, to rozróżnienie na tytuły, które Chrystus przyjął tylko ze względu na stworzenie i te, które posiada ze względu na siebie i na relację z Ojcem. Mariusz Szram słusznie nazywa pierwszą grupę tytułów „funkcyjnymi”, gdyż wskazują one na funkcje jakie Syn spełnia wobec ludzkości, drugą natomiast „ontycznymi”, gdyż odnoszą się do Boskiej natury Syna i Jego jedności z Ojcem ${ }^{29}$. Dla przykładu, tytułami funkcyjnymi są „Pasterz”, „Światłość świata” czy „Pierworodny spośród umarłych”. Syn bowiem nie musiałby nikomu pasterzować, a więc nikogo sprowadzać z błędnej drogi, ani rozświetlać czyichś ciemności, ani nawet umrzeć i zmartwych-

Figlio, w: Origene. Dizionario, s. 164-165; R.E. Heine, Epinoiai, w: The Westminster Handbook to Origen, ed. J.A. McGuckin, Louisville - London 2004, 93-95.

${ }^{26}$ Origenes, Commentarius in Joannem I 9, 52-53, ed. C. Blanc, SCh 120, Paris 1966, 88, tłum. S. Kalinkowski: Orygenes, Komentarz do Ewangelii według św. Jana, ŹMT 27, Kraków 2003, 37-38.

${ }^{27}$ Por. tamże I 28, 200, SCh 120, 158, ŹMT 27, 64: „Niechaj jednak nikt nie podejrzewa, że wprowadzając rozróżnienie między przymiotami Chrystusa robimy to samo w odniesieniu do jego istoty". Zob. także tenże, Contra Celsum II 64; tenże, Commentarius in Epistulam ad Romanos 5, 6. Szerzej na temat jedności Chrystusa według Orygenesa zob. C.A. Beeley, The Unity of Christ: Continuity and Conflict in Patristic Tradition, New Haven - London 2012, 17-45.

${ }^{28}$ Por. Szram, Chrystus - Madrość Boża, s. 64-76.

${ }^{29}$ Por. tamże, s. 77-84. W rzeczywistości jest jeszcze jedna grupa tytułów, które Szram określa jako „ontyczno-funkcyjne”. Ze względu na ściśle określony temat i ograniczony rozmiar niniejszego tekstu pominiemy szczegółową analizę poszczególnych grup tytułów. Zainteresowanego tym zagadnieniem czytelnika odsyłamy do zacytowanej tu monografii Mariusza Szrama, gdzie - oprócz wnikliwych analiz - zostaje również podana obszerna bibliografia dotycząca doktryny o ė $\pi^{i} v o \imath \alpha \iota$. 
wstać, gdyby ludzkość nie oddaliła się od Boga ${ }^{30}$. Jeśli zaś chodzi o tytuły ontyczne, to są nimi z pewnością Moc i Mądrość, choć i te - co nie omieszka zauważyć Orygenes - wskazują również na ważną funkcję Syna względem stworzeń:

„Wiele bytów powstało dzięki uczestnictwu w Mądrości, choć nie poznało tej, przez którą zostały utworzone. Bardzo niewiele istot pojmuje mądrość, nie tylko tę, która dotyczy ich samych, lecz także tę, która dotyczy wielu innych bytów, ponieważ Chrystus jest całą Mądrością. Natomiast każdy mędrzec, we-

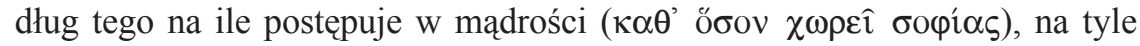

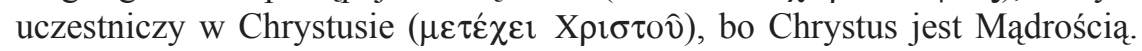
Tak samo każdy, z posiadających moc, w takim stopniu większą otrzymał

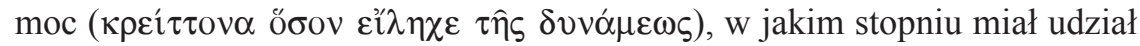
w Chrystusie, który jest Mocą. [...] Gdyby w innych miejscach odnoszących się do Jezusa jako do Mądrości i Mocy nie powiedziano ogólnie, że jest On «Mocą Bożą i Mądrością Bożą» (1Kor 1, 24), moglibyśmy sądzić, że Chrystus

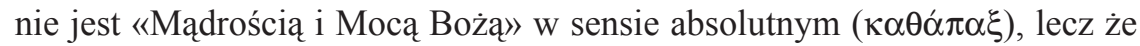
jest nią tylko dla nas. A zatem, co się tyczy mądrości i mocy, to stwierdzono, iż

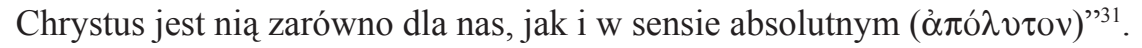

W powyższym tekście Orygenes wyraźnie stwierdza, że stworzenia w różnym stopniu uczestniczą w mocy i mądrości, której pełnią jest Syn - Moc

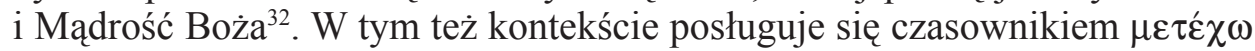
(„mieć udział”, „partycypować”) często używanym przez Platona i platoników przy okazji wykładu teorii partycypacji. Wynika stąd, że według Adamancjusza, cała lub też pełna moc i mądrość Boga nie jest obecna w stworzeniach. Te bowiem posiadają ją jedynie „w takim stopniu, w jakim” (őoov) za nią podążają, bądź też jest ona w nich obecna „na tyle, na ile” (ö $\sigma o v)$ sama

${ }^{30}$ Por. Origenes, Commentarius in Joannem I 20, 120-123. Należy jednak zaznaczyć, że klasyfikacje ċ $\pi^{i} v_{v o l} \alpha$, których dokonuje Orygenes nie są precyzyjne. Znajdujemy bowiem wypowiedzi, z których mogłoby wynikać, że dany tytuł jest typowo funkcyjny, innym razem wydaje się, że zostaje mu przypisany charakter ontyczny. Tak jest w przypadku wspomnianego wyżej „światła” (por. Szram, Chrystus - Madrość Boża, s. 79-80). Światłem bowiem zostaje nazwany w Piśmie nie tylko Syn (por. J 8, 12: „Ja jestem światłością świata”), ale i Ojciec (por. 1J 1, 5: „Bóg jest światłością"). W oparciu o tego typu wypowiedzi Orygenes dowodzi jedności, co do natury, ale i różnicy zachodzącej między osobami Boskimi; zob. Origenes, Commentarius in Joannem II 22, 140 - 23, 157; tenże, Contra Celsum V 11; VIII 12. W takim kontekście tytuł „światło” jest więc rozważany na poziomie ontycznym.

${ }^{31}$ Origenes, Commentarius in Joannem I 34, 245-248, SCh 120, 180-182, ŹMT 27, 72-73 (thum. poprawione).

${ }^{32} \mathrm{~W}$ innym miejscu Orygenes (De principiis II 8, 5, ed. H. Crouzel - M. Simonetti, SCh 252, Paris 1978, 305, ŹMT 1, 193) w następujących słowach wyjaśnia, co znaczy, że Logos jest pełnią mocy i mądrości Boga: „Jak bowiem przenikająca ciało dusza stanowi podstawę jego działań, tak jednorodzony Syn Boży, Słowo i Mądrość Boga, zawierając się w Nim obejmuje całą moc Bożą (pertingit et peruenit ad omnem uirtutem dei, insertus ei)". 
udzieli im czegoś ze swej pełni ${ }^{33}$. W tym miejscu dotykamy interesującego nas zagadnienia. Choć Orygenes nie określa mocy obecnej w świecie jako ordinata, jak ją później nazwie średniowiecze, to jednak podkreśla różnicę, jaka zachodzi między mocą Boga ad extra, a tą, którą Bóg posiada in se $e^{34}$. Tę ostatnią definiuje już jako absoluta, co sugerują użyte w powyższym cytacie dwa terminy greckie: $\kappa \alpha \theta \alpha \dot{\alpha} \pi \alpha \xi$ oraz $\alpha \operatorname{\alpha ó} \lambda v \tau o v$. Jeden i drugi wskazuje na coś absolutnego, czyli bezwzględnego i niczym niezdeterminowanego ${ }^{35}$.

Z powyższego rozróżnienia nie możemy jeszcze wyprowadzać wniosku, że owa absolutna i boska rzeczywistość, w której uczestniczą stworzenia, jest nieskończona. W rzeczywistości bowiem również Platon uważał, że byty materialne uczestniczą w boskich i doskonałych ideach, które przecież, będąc doskonałe, muszą być skończone. Każda idea bowiem, choć ogólna i niecielesna, posiada (bądź wyraża) pewną definicję, która wskazuje na „granice”, poza którymi dany byt nie jest już tym, czym jest. Podobnie może być z mocą

${ }^{33}$ Mówi o tym Orygenes również w innym miejscu (zob. Commentarius in Joannem I 10, 63, SCh 120, 92, ŹMT 27, 39), kiedy stwierdza, że Apostołowie „nie mogliby głosić dóbr, gdyby im Jezus tych dóbr uprzednio nie objawił". A nieco wcześniej (zob. tamże, I 10, 60-61, SCh 120, 90, ŹMT 27, 39) wyjaśnia, że tych dóbr, których pełnią jest Jezus, „Pisma nie ukazują w całości. Cóż mówię: «Pisma», skoro Jan o całym świecie powiada: «Sądzę, że cały ten świat nie pomieściłby ksiagg, które by trzeba napisać» (J 21, 25)". Zob. także tamże I 27, 186, SCh 120, 152, ŹMT 27, 61, gdzie jest mowa o tym, że Syn będąc Prawdą „ogarnia całą wiedzę o wszystkich rzeczach i udziela jej każdemu wedle jego zasług".

${ }^{34}$ Warto w tym miejscu zaznaczyć, że w dziele De Principiis (I 2, 9, SCh 252, ŹMT 1, 93) Orygenes dokonuje dalszych rozróżnień dotyczących już samej tylko mocy istniejącej w Bogu. Komentując bowiem tekst Mdr 7, 25 o tym, że Mądrość ,jest tchnieniem mocy Bożej” stwierdza: „Chodzi tu więc o tę moc, przez którą Bóg żyje, za pomocą której ustanawia i obejmuje wszystkie byty widzialne i niewidzialne oraz kieruje nimi, dzięki której nastarcza wszystkiemu, nad czym sprawuje opatrzność i czym się opiekuje, jakby owa moc była z tym wszystkim zjednoczona. A zatem «tchnienie» i, że się tak wyrażę, siła tej całej olbrzymiej i niezmierzonej mocy istnieje sama w swoim bycie i chociaż wywodzi się z mocy, tak jak wola wywodzi się z umysłu, to jednak i sama wola staje się mocą Bożą. Ta druga moc, która samoistnie bytuje w swych przymiotach, wedle słów Pisma świętego jest jakimś «tchnieniem» pierwotnej i niestworzonej mocy Boga i z niej wywodzi swoje istnienie, a mimo to istnieje odwiecznie”. Rozróżnienie immanentnej i niezrodzonej mocy Boga od mocy Boga subsystującej, czyli Syna, było bardzo niebezpieczne, jak zauważa Simonetti (Origene, I principi, a cura di M. Simonetti, Torino 1979, 155, nota 57), gdyż mogło posłużyć arianom do stwierdzenia, że moc zrodzona, którą jest Syn, nie istniała przed swym zrodzeniem. Nie taka jest jednak intencja Orygenesa, który podkreśla odwieczność również mocy subsystującej. Szerzej

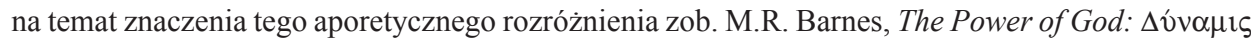
in Gregory of Nyssa's Trinitarian Theology, Washington 2001, 115-124.

${ }^{35}$ Przysłówek $\kappa \alpha \theta \alpha ́ \alpha \alpha \xi$ wskazuje na absolutność w rozumieniu ,jedyności”, „zupełności” czy „bezwzględności” (zob. Abramowiczówna II 534; Liddell - Scott, s. 849). Natomiast przymiotnik

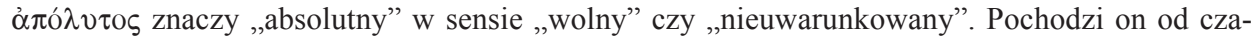
sownika $\alpha \pi \circ \lambda \hat{v} \omega$ - „rozwiązuję”, „uwalniam” (zob. Abramowiczówna I 279-280; Liddell - Scott, s. 208). Również łaciński imiesłów absolutus, którym będą się posługiwali myśliciele średniowieczni pochodzi od czasownika absolvo - „rozwiązuje”, „uwalniam” (zob. C.T. Lewis - C. Short, A New Latin Dictionary, New York - Oxford 1891, 11). 
i mądrością u Orygenesa. Choć w Bogu owa doskonała rzeczywistość jest o wiele potężniejsza, niż ta, którą jest w stanie przyjąć czy ogarnąć stworzenie, to nie wynika stąd, że musi być ona nieskończona. Chociaż człowiek nie posiada wiedzy na temat wszystkich bytów stworzonych przez Boga, jak i tych, które może On stworzyć w przyszłości, nie oznacza to, że zarówno one jak i moc, która je stworzyła, są nieskończone. Nie taki jest jednak faktyczny pogląd myśliciela z Aleksandrii, przez co wyraźnie odcina się od Platońskiej (ale i Arystotelesowskiej) koncepcji doskonałości jako skończoności. Jeśli chodzi o Bożą mądrość, to o jej nieskończoności pisze on w taki oto sposób:

„Jeśli zaś chodzi o tych, którzy zabiegają o mądrość i wiedzę, to ponieważ nie mają one żadnego kresu (finis nullus est) - bo jakiż może być kres Mądrości Bożej (quis enim terminus Dei sapientiae erit)? - zatem im dalej ktoś postapi tym większe napotka głębiny, im bardziej będzie dociekał tym bardziej zrozumie, iż sprawy te są niewyrażalne i niepoznawalne. Niepoznawalna i niezgłębiona (incomprehensibilis et inaestimabilis) jest bowiem Mądrość Boża" ${ }^{\text {"36 }}$.

Warto już w tym miejscu zaznaczyć, że w kontrowersyjnym fragmencie z De principiis (którego analizą zajmiemy się w następnym paragrafie) pojawia się stwierdzenie: quidquid infinitum fuerit, et inconpraehensibile erit (,gdyby coś było nieskończone, byłoby niepojęte") ${ }^{37}$ skąd niektórzy badacze ${ }^{38}$ wyprowadzają wniosek, że moc Boga jest skończona, gdyż w przeciwnym razie Bóg nie byłby w stanie poznawać samego siebie. Tymczasem, w wyżej zacytowanym tekście pochodzącym z Homilii o Księdze Liczb, Orygenes stwierdza wprost, że Mądrość Boga jest nieskończona (nie istnieje w niej żaden finis czy terminus) a w konsekwencji niepoznawalna. Niepoznawalna-oczywiście dla skończonego intelektu - nie dla Boga, o czym jeszcze powiemy niżej. Podążający za mądrością człowiek nigdy więc nie będzie w stanie objąć jej w zupełności (na co wskazuje termin incomprehensibilis), przemierzyć w całości jej głębi, czy też przeliczyć bogactwa jej tajemnic lub idei, które zawiera (na co wskazuje termin inaestimabilis). Do natury nieskończoności należy bowiem to, że niezależnie od tego jak wielka jej część zostanie w jakiś sposób przemierzona, o wiele większy (bo nieskończony) dystans pozostaje jeszcze do przebycia ${ }^{39}$. Podobna myśl zostaje wyrażona w tekście Filokalii zachowa-

\footnotetext{
${ }^{36}$ Origenes, In Numeros homiliae 17, 4, ed. L. Doutreleau, SCh 442, Paris 1999, 288, thum. S. Kalinkowski: Orygenes, Homilie o Księdze Liczb, ŹMT 76, Kraków 2016, 198 (thum. poprawione).

${ }^{37}$ Tenże, De principiis II 9, 1, SCh 252, 352.

${ }^{38}$ Zob. nota nr 1.

${ }^{39}$ Stwierdzenie to jest zgodne z Arystotelesowską definicją nieskończoności jako czegoś, co nigdy i w żaden sposób nie może być przemierzone. Por. Aristoteles, Physica III 204a. Inspiracją dla Orygenesa w sformułowaniu powyższej tezy mogła być jednakże nie tyle sama refleksja nad doktryną Arystotelesa, co podobne wątki egzegetyczne, które znajdujemy we wcześniejszej tradycji aleksandryjskiej. Por. Philo Alexandrinus, De posteritate Caini 17-19. Zob. Mrugalski, Nieskończoność Boga u Orygenesa, s. 450 i 465-470. Tak jak dla Filona symbolem mędrca poszukującego Boga, lecz nie znajdującego Go ze względu na Jego nieskończoność, jest Abraham, tak dla Orygenesa
} 
nym w języku greckim, gdzie Adamancjusz świadom, że w jakiś sposób łamie logikę Arystotelesa ${ }^{40}$ stwierdza, że Umysł Boga ,zawiera w sobie, nieskończone numerycznie idee (’’ $\alpha \varepsilon \imath \rho \alpha \dot{\alpha} \rho \imath \theta \mu \hat{\omega})$ ), choć ,nie można tego uzasadnić za pomocą dowodu" "41. Wie bowiem, że skoro nieskończoność ze swej natury jest nieobejmowalna, to nie powinien jej objąć również Boski Intelekt. Wiara w Bożą wszechwiedzę i w Bożą wszechmoc nakazuje mu jednak utrzymywać, że tak właśnie jest w przypadku Boga. Jego nieskończony Umysł obejmuje nieprzebytą głębię i bogactwo Bożej mądrości.

Wiemy już, że mądrość Boga in se jest nieskończona oraz że stworzenie uczestniczy w niej tylko po części. Należy teraz zbadać, czy podobnie rzecz ma się z mocą Boga. W tym kontekście rodzi się pytanie, czy zakres mocy Boga ogranicza się jedynie do aktu stwórczego i w nim się wyczerpuje, czy też transcenduje wszelką „,miarę i liczbę”, wedle której został urządzony świat stworzony ${ }^{42}$ ? Innymi słowy, czy Bóg może uczynić wszystko, również to, czego nie uczynił, czy też nie może? $Z$ pomocą w rozstrzygnięciu tej kwestii przychodzi nam następujący passus z dzieła Przeciw Celsusowi:

„Zarzuca nam dalej Celsus, że mówimy, iż «Bóg może wszystko», ale nie rozumie sensu tego powiedzenia i nie zdaje sobie sprawy ze znaczenia słów «wszystko» i «może». Nie ma potrzeby odpowiadać tu na ten zarzut, albowiem sam Celsus nie zatrzymuje się przy nim, choć prawdopodobnie mógłby się przy nim uprzeć. Może nie wiedział, jaki zarzut stąd mógłby wydobyć, albo i wiedział, lecz przewidywał, jaką dostanie odpowiedź. Według nas zatem Bóg może dokonać wszystkiego, a czyniąc to nie przestaje być Bogiem, dobrym i mądrym. Celsus zaś, jakby nie rozumiał sensu twierdzenia, że Bóg

symbolem takiego mędrca jest Apostoł Paweł. Podobnie też jak Abraham u Filona, im bardziej podąża za przedmiotem swoich poszukiwań odkrywa coraz większy dystans do przebycia, tak Paweł u Orygenesa, im bardziej pragnie zgłębić Mądrość Boga napotyka coraz więcej rzeczy do przebadania. Zob. Origenes, De principiis IV 3, 14, ed. H. Crouzel - M. Simonetti, SCh 268, Paris 1980, 392, ŹMT 1, 365-366: „[Apostoł Paweł] nie powiedział przecież, że z trudnością można zbadać wyroki Boże, lecz że wcale nie można ich zbadać; nie powiedział, że z trudnością można ogarnąć Jego drogi, lecz że nie można ich ogarnąć (por. Rz 11,33). Choćby bowiem nie wiadomo jak bardzo się ktoś przykładał do badań i w usilnym staraniu czynił postępy, nawet wspomagany łaską Bożą i oświecony w umyśle, nie zdoła dotrzeć do doskonałego celu badanych spraw. I żaden stworzony umysł nie może pojąć w żaden sposób, lecz gdy znajdzie cokolwiek z tego, czego szuka, widzi dalsze problemy, które trzeba zbadać; a jeśli i te rozstrzygnie, ujrzy znowu jeszcze więcej zagadnień, które powinny zostać zbadane".

${ }^{40}$ Por. Aristoteles, Physica III 205a - 207b, gdzie Arystoteles dowodzi, że nieskończoność jest nieobejmowalna. Dlatego też nie może istnieć według niego żaden nieskończony byt aktualny, gdyż każdy taki byt posiada formę, a forma jest czymś, co go obejmuje. Nieobejmowalna ex definitione nieskończoność nie może być jednak przez nic objęta.

${ }^{41}$ Origenes, Philocalia XXIII 20, ed. É. Junod, SCh 226, Paris 1976, 198, thum. K. Augustyniak: Orygenes, Filokalia, Warszawa 1979, 210. Na temat nieskończonej wiedzy Boga zob. także Origenes, Selecta in Psalmos 144, PG 12, 1673A. Por. P. Tzamalikos, Origen: Philosophy of History \& Eschatology, Leiden 2007, 175-176; Mrugalski, Nieskończoność Boga u Orygenesa, s. 469-470.

${ }^{42}$ Por. Mdr 11, 20; Origenes, De principiis II 9, 1. 
może wszystko, powiada, iż «Bóg nie chce niczego niesprawiedliwego»; zakłada więc, że Bóg może czynić niesprawiedliwość, ale nie chce. My natomiast twierdzimy, że jak rzecz z natury słodka nie może sama z siebie uczynić słodyczy gorzką, jak naturalna jasność nie może powodować ciemności, tak i Bóg nie może czynić niesprawiedliwości. Zdolność bowiem czynienia niesprawiedliwości sprzeciwia się Jego boskiej naturze i Jego wszechmocy. Natomiast, jeśli któryś z bytów może czynić niesprawiedliwość ze względu na to, że posiada inklinację do czynienia niesprawiedliwości, to może ją czynić o ile w jego naturze nie zawiera się to, że nigdy nie może czynić niesprawiedliwości"43.

Spróbujmy najpierw zrekonstruować zarzut Celsusa, do którego w powyższym tekście odnosi się Orygenes. Musiał on być sformułowany mniej więcej w taki oto sposób ${ }^{44}$ : skoro człowiek, choć posiada inklinację do czynienia niesprawiedliwości, potrafi również być sprawiedliwy, to także Bóg, choć z natury jest skłonny do czynienia sprawiedliwości, powinien być w stanie czynić niesprawiedliwość. Chrześcijanie bowiem twierdzą, iż «Bóg może wszystko» ${ }^{45}$. Z tak postawionym zarzutem Adamancjusz radzi sobie odwołując się do pojęcia natury poszczególnych bytów i właściwych im inklinacji. Do natury człowieka nie należy bycie niesprawiedliwym, choć taka skłonność daje się zaobserwować w jego działaniu. Jego natura w gruncie rzeczy jest dobra, lecz nie istotowo dobra. $Z$ tego powodu człowiek może czynić również zło, gdyż nie uniemożliwia mu tego jego natura. Nie jest w nią bowiem wpisana niemożliwość czynienia zła. Inaczej jest w przypadku Boga, który jest istotowo

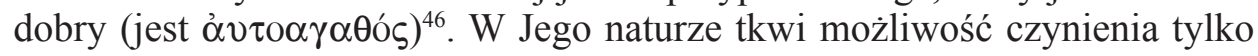

${ }^{43}$ Origenes, Contra Celsum III 70, ed. M. Borret, SCh 136, Paris 1968, 158-160, thum. S. Kalinkowski: Orygenes, Przeciw Celsusowi, Warszawa 1986, 178 (thum. zmienione w ostatnim zdaniu).

${ }^{44}$ Wskazuje na to ostatnie zdanie powyższej wypowiedzi, w którym zostaje wyjaśniona kwestia tego, co znaczy działać zgodnie z naturą w przypadku człowieka i w przypadku Boga.

${ }^{45} \mathrm{Z}$ podobnym oskarżeniem spotykamy się w dalszej części dzieła, kiedy zostaje poruszona kwestia zmartwychwstania ciała - według Celsusa absurdalna i niezgodna z rozumem. W tym kontekście Orygenes przytacza dość obszerną wypowiedź adwersarza chrześcijan. Zob. Origenes, Contra Celsum V 14, ed. M. Borret, SCh 147, Paris 1969, 48-50, tłum. S. Kalinkowski, s. 255: „Jakież bowiem ciało całkowicie rozłożone może powrócić do pierwotnej formy i odzyskać budowę, którą raz utraciło? Gdy [chrześcijanie] nie potrafią rozsądnie na to odpowiedzieć, chwytają się bzdurnej obrony twierdząc, że Bóg wszystko może. Tymczasem Bóg nie może spełnić nic wstrętnego, ani nie pragnie niczego, co jest przeciwne naturze. Nie wypada wierzyć, że jeślibyś w swej występności zapragnął czegoś niegodziwego, Bóg będzie mógł tego natychmiast dokonać, albo że się to spełni. Albowiem Bóg kieruje światem nie po to, aby spełniać występne kaprysy albo folgować nieuporządkowanym pragnieniom, lecz po to, aby się opiekować prawą i sprawiedliwą naturą [...]. On bowiem jest Rozumem wszystkich bytów; niczego zatem wbrew rozumowi ani przeciw samemu sobie nie może dokonać".

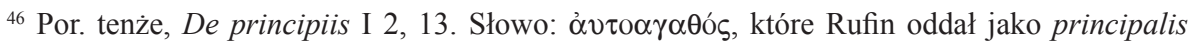
bonitas (SCh 252, 53) pojawia się we fragmencie cytowanym przez Justyniana. Zob. Justinianus Imperator, Epistula ad Mennam Constantinopolitanum, Mansi IX 525 = SCh 253, 53. Por. także Origenes, Commentarius in Joannem I 35, 253-253; XIII 25, 151-153. 
dobra, tak jak do natury słodyczy należy czynienie rzeczy słodkimi (nigdy zaś gorzkimi), a do natury światła należy rozświetlanie ciemności (nie zaś ich sprowadzanie). Choć czynienie zła jest sprzeczne z naturą Boga, nie umniejsza to wcale Jego mocy, gdyż - jak dowodzi w innym miejscu Orygenes - zło jest niebytem ( je, nie posiada większej mocy od tego, który nie czyni tego, co nie istnieje. Ponadto Bóg może czynić dobro na nieskończoną ilość sposobów. Ma moc czynienia takiego dobra, którego świat jeszcze nie doświadczył i nie poznał. W tym sensie Jego moc przewyższa nie tylko tę moc, którą posiada człowiek, lecz wszelką moc, która w skończony sposób objawiła się w stworzeniu. Jeżeli do natury dobra należy udzielanie się, tak jak do natury światła oświecanie, a słodyczy osładzanie, to owa dobroczynna moc nie powinna wyczerpać się w samym tylko akcie stwórczym. Bóg może więc nieustannie stwarzać rzeczy nowe, ale także przenosić istniejące już byty rozumne z poziomu natury na poziom tego, co nadnaturalne. Dzieje się to wtedy, gdy stworzenia otwieraja się na Jego moc, która transcenduje wszelką skończoną naturę stworzoną̨ ${ }^{48}$.

W Komentarzu do Ewangelii Mateusza Orygenes zdaje się jednak poszerzać absolutną moc Boga nawet do teoretycznej możliwości uczynienia tego, co niesprawiedliwe. Komentując bowiem zdanie wypowiedziane przez Jezusa podczas modlitwy w ogrodzie oliwnym: „Jeśli to możliwe, niech Mnie ominie ten kielich" (Mt 26, 39), stwierdza:

„[Jezus] chciał więc, aby ten kielich męki zasadniczo Go ominął tak, aby w ogóle nawet nie zakosztował jego goryczy, jeśli jednak byłoby to możliwe ze względu na sprawiedliwość Boga. Bo mówiąc: «jeśli to możliwe» uwzględniał nie tylko samą moc Boga (potentiam dei), lecz także Jego sprawiedliwość: ponieważ ze względu na moc Boga wszystko jest możliwe (quantum ad potentiam quidem dei omnia possibilia sunt), czy to sprawiedliwe czy nie-

${ }^{47}$ Por. Origenes, Commentarius in Joannem II 13, 96, SCh 120, 270. Warto w tym miejscu zaznaczyć, że stwierdzenie, iż „zło jest niebytem” pojawia się w komentarzu do zdania z Janowego Prologu (J 1, 3): „Wszystko przez Nie się stało, a bez Niego nic się nie stało”. Owo „nic” (oủ Év),

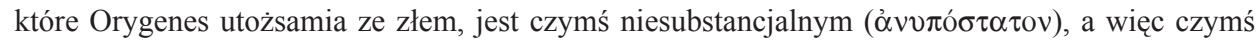

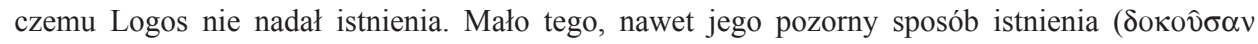
$\sigma u ́ \sigma \tau \alpha \sigma \iota v)$ nie pojawił się w świecie ani za sprawą Boga, ani za pośrednictwem Logosu. Zob. tamże II 13, 92-96, SCh 120, 266-270. Niemożliwość stworzenia zła nie umniejsza więc wszechmocy Boga, lecz jest koniecznością logiczną: to, co nie jest, nie zostało stworzone.

${ }^{48}$ Por. tenże, Contra Celsum V 23-24, SCh 147, 70-72, thum. S. Kalinkowski, s. 261, gdzie Orygenes powtarza po części argumentację, którą spotkaliśmy już w Contra Celsum III 70, ale także w pewien sposób ją poszerza. Odnosząc się bowiem do zarzutu Celsusa o irracjonalności wiary w zmartwychwstanie ciała, stwierdza, że Bóg, również według chrześcijan, nie może czynić rzeczy sprzecznych z rozumem i sprzecznych z naturą. Rzeczą sprzeczną z Boskim rozumem i Boską naturą jest jednak tylko i wyłącznie zło, gdyż Bóg jest istotowym Dobrem i źródłem wszelkiego dobra. Nie jest więc sprzeczne z natura, jeśli Bóg czyni coś dobrego, co przekracza naturę stworzoną, na przykład gdy „wynosi człowieka ponad ludzką naturę, czyniąc go uczestnikiem lepszej i boskiej natury”. W ten sposób bowiem Bóg jeszcze bardziej ujawnia swoją dobroć, a nie jej zaprzecza. 
sprawiedliwe, ze względu zaś na sprawiedliwość Jego - który jest nie tylko mocny ale i sprawiedliwy - nie wszystko jest możliwe, lecz tylko to, co jest sprawiedliwe" 49 .

Niesprawiedliwość, o której w powyższym tekście mówi Orygenes nie jest zapewne złem, którego Bóg z natury uczynić nie może. Chodzi tu raczej o możliwość uniknięcia zbawczej męki Jezusa, co Adamancjusz wyjaśnia w dalszej części swojego wywodu. Teoretycznie było więc możliwe, aby Chrystus nie cierpiał i nie umarł. Gdyby jednak tak się stało, rodzaj ludzki nie zostałby usprawiedliwiony. Nie objawiłaby się wówczas sprawiedliwość Boża polegająca na odpuszczeniu grzechów (por. Rz 3, 25-26), a grzeszny człowiek nadal pozostawałby dłużnikiem Boga (por. Rz 8,12). Chrystus jednak umarł za wszystkich (por. 2Kor 5, 15), aby wszystkich ominęła wieczna śmierćs ${ }^{50}$. Stwierdzając więc, że ,ze względu na moc Boga wszystko jest możliwe”, lecz „ze względu na sprawiedliwość Jego tylko to, co jest sprawiedliwe”, myśliciel aleksandryjski nie rozszerza absolutnej mocy Boga na możliwość uczynienia „niesprawiedliwości”. Sprawiedliwość Boga bowiem utożsamiona zostaje tutaj z miłosierdziem. Bóg mógłby nie okazać miłosierdzia i nie spłacić długu grzesznego człowieka, i nie okazałby się przez to niesprawiedliwym. To nie On wszakże zaciagnął dług poprzez uczynioną niesprawiedliwość, lecz człowiek. Ponieważ jednak jest miłosierny, chce dokonać tego, czego ze względu na swoją absolutną moc czynić nie musi ${ }^{51}$.

Wiemy już, że absolutna moc Boga może wszystko z wyjątkiem tego, co przeciwstawia się naturze Boga, a więc z wyjątkiem zła, które zresztą, jak już

${ }^{49}$ Tenże, Commentariorum in Matthaeum series (Mt 26, 42) 95, ed. E. Klostermann, GCS 38, Leipzig 1933, 213, thum. K. Augustyniak: Orygenes: Komentarz do Ewangelii wedlug św. Mateusza (Część druga: Commentarium series), ŹMT 25, Kraków 2002, 163.

${ }^{50}$ Por. tamże, GCS 38, 313-214.

${ }^{51}$ Warto w tym miejscu zaznaczyć, że średniowieczny spór dotyczący potentia Dei absoluta et ordinata, rozpoczął się od rozprawy Piotra Damianiego, w której zostaje sformułowana bardzo podobna teza do tej, którą znajdujemy w wyżej analizowanych tekstach Orygenesa. Zob. Petrus Damianus, De divina omnipotentia 4, ed. A. Cantin, SCh 191, 400-402, Paris 1972, thum. M. Gensler: Piotr Damiani, O Boskiej wszechmocy. Rozprawa o tym, w jaki sposób Bóg, jeśli jest wszechmogacy, może sprawić, żeby to, co się stało, się nie stało, w: Antologia tekstów filozoficznych i teologicznych z III-XI wieku, red. E. Jung, Kraków 2012, 252: „Tego, co złe, Bóg nie może uczynić, ponieważ nie może tego także chcieć. Nie należy jednak tego składać na karb niemocy, lecz raczej naturalnego dobra [Jego] szczególnej łaskawości. Wszak to, co jest dobre, może i chcieć, i sprawić, nawet jeśli wskutek swej przezorności lub przedwiedzy niektóre dobra sprawia rzadko lub wcale. Inaczej można by było powiedzieć przed przyjściem Zbawiciela, że Bóg nie może sprawić, iż Syn zrodzi się z łona dziewicy: nie jest dziwne, że nigdy nie był tego zrobił, lecz tak samo nie jest dziwne, że tylko raz miał to zrobić. A jeśli nawet nigdy by tego nie zrobił, to przecież i chciał, i mógł to uczynić, bo było to czymś dobrym". W dalszej natomiast części tej samej rozprawy czytamy (tamże 17, SCh 191, 474, tłum. Gensler, s. 274): „Doprawdy, jaką siłą Bóg może wszystko? Jaką mądrością zna wszystko? Zapytajmy Apostoła: «Chrystusem - odpowiada - mocą Bożą i mądrością Bożą» (1Kor 1, 24). To w Nim jest prawdziwa wieczność, prawdziwa nieśmiertelność, w Nim owo wieczne dzisiaj, które nigdy nie przemija". 
widzieliśmy wyżej, jest niebytem. Warto jednak przyjrzeć się jeszcze temu, w jaki sposób owa moc objawia się pośród stworzeń. Teoretyczne rozważania na temat tego, co Bóg może, lecz nie chce czynić, lub może, ale jeszcze nie uczynił, prowadzą do wniosku, że według Orygenesa Bóg działa w świecie posługując się tylko pewnym wymiernym zakresem swej absolutnej mocy. O tej wymiernej czy też w jakiejś mierze ograniczonej mocy pisze Adamancjusz wprost przy okazji interpretacji ewangelicznej perykopy o cudzie, który wyprosiła kobieta kananejska (por. Mt 15, 21-28). Jej wiara bowiem niejako wymusiła otwarcie się źródła nadprzyrodzonej mocy, która pierwotnie nie była dla niej przeznaczona. W tym kontekście Orygenes zastanawia się, co mogły znaczyć mocne słowa Zbawiciela, skierowane do kobiety: „Niedobrze jest zabrać chleb dzieciom a rzucić szczeniętom" (Mt 15, 26):

„Bo jeśli liczba chlebów była ograniczona, tak iż nie było możliwe nakarmić nimi i dzieci, i szczenięta domu, albo jeśli chleby były wytwornie przygotowane, tak iż nie byłoby rozumnie dawać szczeniętom luksusowy chleb dzie-

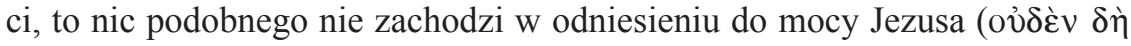

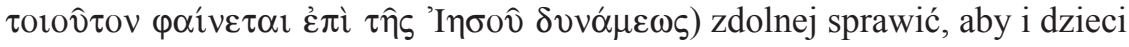
otrzymały swoją część, i ci, którzy nazwani są szczeniętami. Rozważ zatem, czy dla wyjaśnienia słów: «Niedobrze jest zabrać chleb dzieciom» nie trzeba powiedzieć, że Ten, który «ogołocił samego Siebie, przyjąwszy postać sługi» (Flp 2,7), uzyskał określoną tylko ilość mocy ( $\mu \varepsilon ́ \tau \rho o v ~ \delta v v \alpha ́ \mu \varepsilon \omega \varsigma)$ stosownie do tego, ile objąć jej są zdolne sprawy tego świata; i kiedy pewna część tej mocy wychodziła z Niego, zauważył to, jak wskazuje tekst: «Ktoś się Mnie dotknął, bo poznałem, że moc wyszła ode Mnie» (Łk 8, 46). Tą określoną

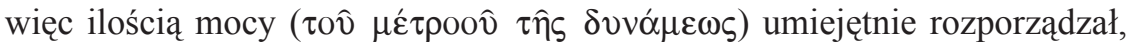
użyczając więcej duszom wybranym, które oznaczone zostały jako dzieci, a mniej innym, które nie miały tej jakości, jako szczeniętom. Ale chociaż tak było, tym niemniej tam, gdzie odkrył wielką wiarę, dał chleb dzieci, jak dziecku, tej kobiecie, która wskutek nieszlachetnego pochodzenia z ziemi Kanaan była szczenięciem"s2.

$\mathrm{Na}$ początku powyższego tekstu myśliciel aleksandryjski wysuwa dwie następujące hipotezy odnośnie do mocy, którą dysponował wcielony Logos. Po pierwsze, mogło być tak, iż Zbawiciel posiadał zbyt mało owej Boskiej mocy i dlatego stwierdził: „Niedobrze jest zabrać chleb dzieciom a rzucić szczeniętom". Po drugie, natura jego Boskiej mocy mogła być niedostosowana do natur pewnej grupy ludzi, którzy ze względu na jej wielkość nie byli w stanie jej przyjąć (argument pojawiający się zapewne w kręgach gnostyckich). Adamancjusz odrzuca jednak pierwszą i drugą hipotezę stwierdzając:

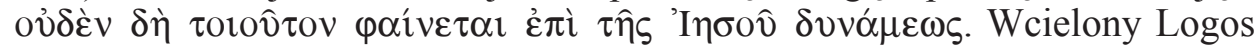

${ }^{52}$ Origenes, Commentarius in Matthaeum XI 17, ed. R. Girod, SCh 162, Paris 1970, 366-368, tłum. K. Augustyniak: Orygenes, Komentarz do Ewangelii wedlug św. Mateusza, ŹMT 10, Kraków 1998, 102. 
posiadał więc wystarczającą ilość mocy, a zarazem natura tej mocy była odpowiednio dostosowana do tego, aby mogli ją przyjać wszyscy ludzie, zarówno ci, którzy należeli do ludu wybranego, jak i ci, którzy do niego nie należeli.

Dziwić jednak może, że myśliciel aleksandryjski nie odrzuca in toto innej hipotezy, a mianowicie, że Syn Boży podczas swej ziemskiej działalności mógł dysponować określoną tylko ilością Bożej mocy „stosownie do tego, ile objąć jej są zdolne sprawy tego świata". Choć moc ta byłaby wystarczająco potężna, aby czynić dobrodziejstwa tak dla wybranych, jak i dla pogan, tak dla posiadających wiare, jak i dla tych, którzy jej nie posiadają $a^{53}$, to jednak nie stanowiłaby całości absolutnej mocy, jaka istnieje w Bogu. W tym kontekście Orygenes

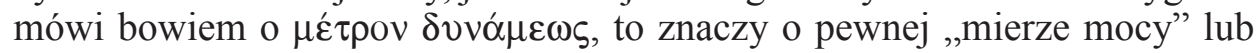
„wielkości mocy” dostępnej Temu, który - jak przecież mówi Pismo - „ogołocił samego Siebie, przyjąwszy postać sługi” (Flp 2, 7). Niezależnie jednak od tego, czy wcielony Logos posiadał na ziemi pełnię Bożej mocy, czy też tylko pewną jej miarę (należy pamiętać, że Adamancjusz umiera na około 200 lat przed Soborem Chalcedońskim, który dokonał precyzyjnych rozróżnień odnośnie do dwóch natur Chrystusa ${ }^{54}$, a także o tym, że jego wypowiedź ma charakter hipotezy ${ }^{55}$ ), to i tak owa miara ( $\left.\mu \dot{\varepsilon} \tau \rho o v\right)$ przewyższała możliwości przyjmujących ją stworzen ${ }^{56}$. Mało tego - $\mathrm{i}$ to jest istotne dla naszego tema-

${ }^{53}$ Mówi o tym Adamancjusz nieco wcześniej, w tym samym dziele, kiedy komentuje wypowiedź z Mt 13, 58 o tym, że Jezus w swym rodzinnym mieście „niewiele zdziałał cudów, z powodu niedowiarstwa" jego mieszkańców. Zob. Origenes, Commentarius in Matthaeum X 19, SCh 162, 232, ŹMT 10, 66: „Mateusz i Marek chcieli, jak mi się zdaje, wyraźnie wskazać na wyższość mocy

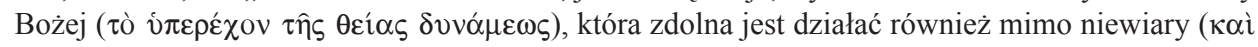

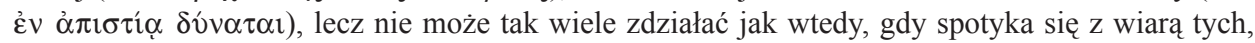
co korzystają z dobrodziejstwa cudu: dlatego Mateusz nie powiedział, że «nie zdziałał cudów z powodu ich niedowiarstwa», lecz że «niewiele zdziałał tam cudów z powodu ich niedowiarstwa»; a Marek nie poprzestał na stwierdzeniu: «I nie mógł tam zdziałać żadnego cudu», lecz dorzucił: «jedynie na kilku chorych położył ręce i uzdrowił ich» (Mk 6, 5), ponieważ moc, która była w Nim i w tych warunkach przemogła niewiarę".

${ }^{54}$ Por. Concilium Chalcedonense (451), Definitio fidei 11, tekst grecko-łacińsko-polski, układ i oprac. A. Baron - H. Pietras, tłum. T. Wnetrzak, ŹMT 24 = DSP 1, Kraków 2001, 222.

${ }^{55}$ Odnośnie do wyrażonej w powyższym cytacie hipotezy, należy również podkreślić, że w innych miejscach Orygenes stwierdza, że Syn, „stawszy się człowiekiem nie przestał być tym, czym był - Bogiem" (Origenes, De principiis, Praefatio 4, SCh 252, 80, ŹMT 1, 53) oraz że również po wcieleniu Ojciec ,przebywa z Nim i jest w Synu, tak jak Syn jest w Ojcu” (tenże, Commentarius in Joannem XX 18, 155, ed. C. Blanc, SCh 290, Paris 1982, 232, ŹMT 27, 422). Por. Beeley, The Unity of Christ, s. 17-22.

${ }^{56} \mathrm{O}$ tym, że moc, którą posiada Zbawiciel przewyższa możliwości przyjmujących ją stworzeń, Orygenes mówi w innym jeszcze miejscu, kiedy to komentuje dialog Jezusa z faryzeuszami dotyczący Jego Boskiego pochodzenia (por. J 8, 19-25). Zauważa przy tej okazji, że Słowo, którego nie może ogarnąć nawet świat cały w jakimś sensie musi ograniczyć swą moc również po to, aby mogło być pojmane i ukrzyżowane. Kiedy bowiem przemawia, a więc kiedy działa Jego moc, jest to niemożliwe. Zob. Origenes, Commentarius in Joannem XIX 10, 59-61, SCh 120, 270 ŹMT 27, 376-377: „Jezus jednak nauczając przy skarbcu nie wypowiedział wszystkich słów, lecz tyle tylko, ile skarbiec mógł pomieścić. Bo przecież, jak sądzę, cały ten świat nie może ogarnąć całego Słowa 
tu - moc, którą posiadał Zbawiciel, była przez Niego w umiejętny sposób rozdysponowywana. Jedne dusze zatem otrzymywały więcej, inne mniej z tej przewyższającej wszelkie stworzenie mocy. W ten sposób Orygenes własnymi słowami potwierdza drugą część hipotezy, którą wysunęliśmy na początku niniejszego tekstu, a mianowicie o istnieniu potentia Dei ordinata. Tak więc Bóg nie tylko stwarza świat według „liczby i miary”, lecz także wedle pewnej miary oraz w pewien racjonalny i uporządkowany sposób udziela swej mocy stworzeniom gotowym na jej przyjęcie. W świecie obecna jest więc i działa potentia Dei ordinata. Ta sama moc jednak, jak już to zostało wykazane powyżej, w Bogu jest nieskończona i niczym niezdeterminowana, dlatego można ją określić jako potentia Dei absoluta.

Warto w tym miejscu wspomnieć jeszcze o wypowiedzi, którą znajdujemy w niedawno odkrytym manuskrypcie (Codex Monacensis Graecus 314) zawierającym 29 Homilii do Psalmów Orygenesa. Pojawia się w niej bowiem termin

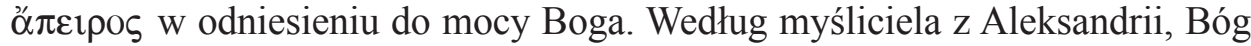
jest więc dobroczynną aktywnością rozciągającą się od nieskończoności w nieskończoność, a sposoby Jego udzielania się światu, choć zawsze dostosowane do możliwości przyjmujących je stworzeń, są również nieskończone. Do takiego wniosku dochodzi Adamancjusz łącząc dwa teksty biblijne, w których pojawia się stwierdzenie o niepoznawalnych drogach i śladach Boga. Pierwszym z nich jest werset Psalmu 76, 20: „Twoja droga wiodła przez wody, Twoja

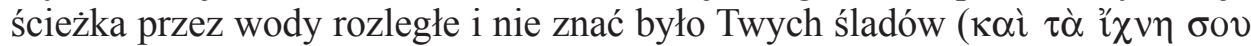
ov̉ $\gamma \nu \omega \sigma \theta \eta ் \sigma o v \tau \alpha \imath)$ ". Drugim zaś wypowiedź Apostoła, który mówiąc o „głębokości bogactw, mądrości i wiedzy Boga” zakrzykuje: „Jakże niezbadane są

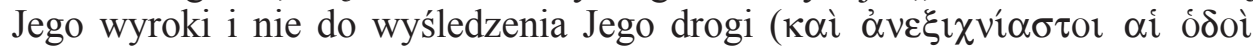

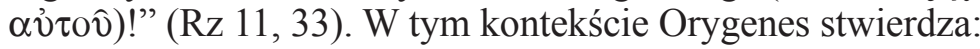

„Jak bowiem człowiek chcąc wyrobić sobie pogląd na temat pojęcia śladów

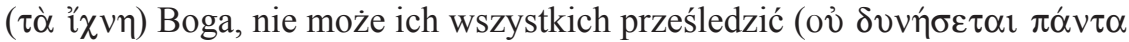
$\grave{\varepsilon} \xi \imath \chi v i \alpha ́ \sigma \alpha \imath)$, tak też [nie może prześledzić] tego, czego Bóg pragnie na nie-

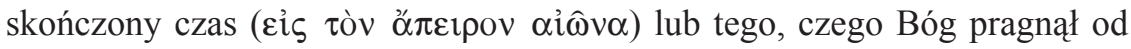

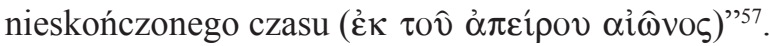

Podobnie, jak w wyżej cytowanych fragmentach dotyczących mądrości, mędrzec nie był w stanie przemierzyć głębin Bożej mądrości, tak teraz Orygenes stwierdza, że człowiek nie jest w stanie prześledzić wszystkich ,śla-

Bożego (por. J 21, 25). Gdy Jezus wypowiedział takie słowa przy skarbcu i kiedy nauczał w świątyni, nikt Go nie pojmał. Jego słowa bowiem były potężniejsze od tych, którzy chcieli Go pochwycić. Kiedy więc przemawia, nie uwięzi Go nikt spośród tych, którzy spiskują przeciw Niemu, a zostanie pojmany wówczas, kiedy zamilknie. Otóż kiedy miał cierpieć za świat, milczał wypytywany przez Piłata i biczowany, gdyby bowiem przemówił, nie zostałby ukrzyżowany w słabości, ponieważ nie ma słabości w tym, co mówi Słowo".

${ }^{57}$ Por. tenże, In Psalmos homiliae, Homilia IV in Psalmum LXXVI, 212-213, GCSNF 19, ed. L. Perrone - M. Molin Pradel - E. Prinzivalli - A. Cacciari, Berlin - München - Boston 2015, 349, tłum. własne. 
dów" ( $\tau \grave{\alpha}$ ¿̌ $\chi \eta)$, to znaczy przejawów mocy Boga w świecie. Choć powyższy fragment dotyka zagadnienia nieskończoności w sensie czasowym, to jednak sugeruje, iż Bóg może używać swej mocy względem stworzeń na nieskoń-

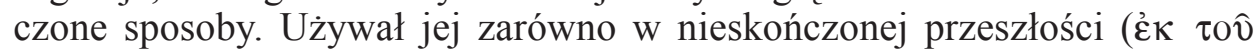

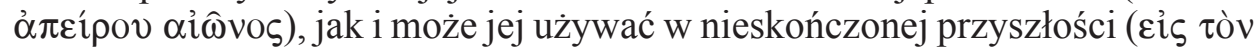

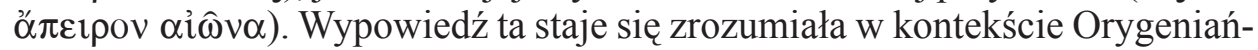
skiej doktryny o stworzeniu, według której Bóg istniejący z nieskończoności w nieskończoność zawsze posiadał stworzenia, nad którymi sprawował swą władzę, gdyż - jak wyjaśnia Adamancjusz - On zawsze był dobry i zawsze udzielał swej dobroci stworzeniom ${ }^{58}$. Upadek tych ostatnich nie spowodował zaprzestania dobroczynnej aktywności Boga. Tak jak w przeszłości, tak i w przyszłości będzie On znajdował coraz to nowe sposoby prowadzące do ich zbawienia. Stwierdzenie to nie oznacza oczywiście tego, że w Bogu, który jest poza czasem, pojawi się coś nowego, jakiś nowy sposób działania, którego by uprzednio nie znał. Owa nowość dotyczy stworzenia zanurzonego w czasie, które staje się depozytariuszem zawsze nowych darów pochodzących od nieustannie udzielającego się Dobra. Skończony ludzki intelekt nie jest więc w stanie objąć i pojąć w całości tego, co w każdym przedziale czasowym jawi się jako nowe. Dlatego też Orygenes powtarza za Psalmistą, ale i za apostołem Pawłem, że drogi Boże są nie do wyśledzenia ( $\alpha v \varepsilon \xi ı$ í

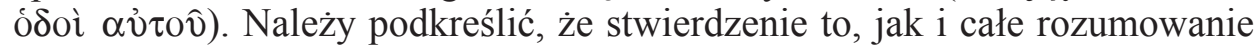
Aleksandryjczyka, jest zgodne z definicją nieskończoności, jaką znajdujemy u Arystotelesa: nieskończoność jest czymś, czego nie można prześledzić59. Człowiek może wprawdzie dostrzec i zrozumieć niektóre z Bożych ,śladów” obecnych w świecie, to znaczy te, które objawiają się w pewnym skończonym przedziale czasowym i w pewien skończony sposób (potentia Dei ordinata), lecz z pewnością nie wszystkie. Działająca bowiem z nieskończoności w nieskończoność moc Boga (potentia Dei absoluta) jest nie do prześledzenia, a przez to nieobejmowalna i niepoznawalna przez ludzki intelekt ${ }^{60}$.

${ }^{58}$ Por. tenże, De principiis I 4, 3, SCh 252, 170, ŹMT 1, 95: „Wcale więc nie można wyobrazić sobie takiego momentu, w którym ta dobroczynna moc nie czyniła dobrze. Wynika stąd konsekwentny wniosek, że zawsze też istniały byty, którym ta moc czyniła dobrze - mianowicie jej stworzenia; a czyniąc dobrze udzielała im dobrodziejstw mocą opatrzności w porządku i wedle zasługi. Trzeba też przyjąć, że nie było takiego momentu, w którym Bóg nie był Stworzycielem, Dobroczyńcą i Opiekunem".

${ }^{59}$ Por. Aristoteles, Physica III 204a 2-7, ed. I. Bekker: Aristotelis opera edidit Academia Regia Borussica, vol. 1, Berlin 1831, 204, thum. K. Leśniak: Arystoteles, Zachęta do filozofii. Fizyka, Warszawa 2010, 124: „Należy więc przede wszystkim zacząć od określenia różnych znaczeń, jakie się nadaje pojęciu nieskończoności. W pierwszym znaczeniu będzie nią to, co z natury swej nie może być prześledzone, jak np. głos, który jest niewidzialny. Po drugie będzie nią to, co może być śledzone, jednakże proces ten nie można doprowadzić do końca. Albo to, co z trudem tylko da się prześledzić. Wreszcie to, co z natury swej może być przedmiotem badania, lecz dokładnie nie da się prześledzić, albo nie ma granicy".

${ }^{60}$ Dla całości obrazu omawianego przez nas zagadnienia chciałbym wspomnieć o jeszcze jednym ważnym temacie Orygeniańskim, przy okazji którego pojawia się również kwestia nieskoń- 
3. Kontrowersyjne fragmenty jako potwierdzenie teologicznych rozróżnień. Powyższe rozróżnienia, które znajdujemy zarówno $\mathrm{w}$ tekstach zachowanych w języku greckim, jak i tych które dotarły do nas w języku łacińskim, są na tyle ewidentne, że w zasadzie nie potrzeba dowodzić dalej, że Orygenes, kiedy mówi o skończonej mocy Boga działającej w świecie, ma na myśli jedynie pewien zakres nieskończonej mocy, która istnieje w Bogu. Ponieważ jednak, jak wspomnieliśmy na wstępie, niektórzy historycy idei powołują się na cztery fragmenty tekstów, z których miałoby wynikać, iż myśliciel aleksandryjski odziedziczył po filozofach greckich negatywne rozumienie nieskończoności, należy przyjrzeć się również i tym wypowiedziom. Pominiemy tu analizę dwóch z nich, a mianowicie fragmentu z dzieła $O$ zasadach III 5, 2 oraz z Komentarza do Ewangelii wedtug św. Mateusza XIII 1. Czynimy tak dlatego, że po pierwsze cytowaliśmy i analizowaliśmy te fragmenty w innym miejscu $^{61}$, a po drugie, gdyż nie ma w nich wprost mowy o skończonej mocy Boga. Orygenes stwierdza tam po prostu, że świat i liczba stworzeń w nim istniejących musi mieć swój początek i koniec, gdyż w przeciwnym razie nawet sam Bóg nie mógłby ogarnąć tego, co nieskończone. Dwa pozostałe fragmenty natomiast, zachowane $\mathrm{w}$ języku greckim, jak i w thumaczeniu łacińskim Rufina, zawierają wzmiankę o skończonej mocy Boga, choć pojawia się ona jedynie w wersji greckiej. Oto pierwszy z nich:

\begin{tabular}{|c|c|}
\hline Tłumaczenie De principiis Rufina & Fragment De principiis u Justyniana \\
\hline „Powinniśmy zatem uznać, iż na owym & „Na poczatku, który można sobie rozu- \\
\hline początku Bóg uczynił taka ilość stworzeń & mowo wyobrazić, Bóg z własnej woli \\
\hline rozumnych albo umysłowych - czy jak & stworzył taką ilość bytów rozumnych, \\
\hline tam należy nazwać byty, które określili- & jakiej mógł nastarczyć; trzeba bowiem \\
\hline śmy powyżej jako umysły - jaka w Jego & stwierdzić, że moc Boża jest ograniczo- \\
\hline
\end{tabular}

czoności Boga, a mianowicie o rozróżnieniu na teologię i ekonomię. Zob. Origenes, In Ieremiam homilae 18, 6, ed. P. Nautin - P. Husson, SCh 238, Paris 1977, 198, thum. S. Kalinkowski: Orygenes, Homilie o Księdze Jeremiasza. Komentarz do Lamentacji Jeremiasza. Homilie o Księgach Samuela i Księgach Królewskich, PSP 30, Warszawa 1983, 157: „Kiedy Pismo w sposób teologiczny mówi o istocie Boga i nie łączy zbawczej ekonomii z ludzkimi sprawami, wówczas stwierdza, że «Bóg nie jest jak człowiek» $(\mathrm{Lb} 23,19)$. Na przykład: «Wielkość jego nie będzie mieć kresu ( $\mu \varepsilon \gamma \alpha \lambda \omega \sigma \tilde{v} \eta \varsigma$

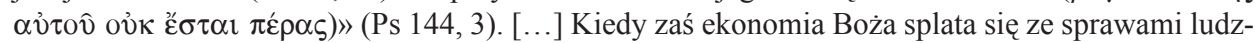
kimi, wówczas Bóg przybiera ludzki rozum, ludzki sposób postępowania i ludzki styl wysłowienia”. $\mathrm{Z}$ istotą Boga wiąże więc Orygenes wielkość (oczywiście nie w sensie fizycznym), która nie ma

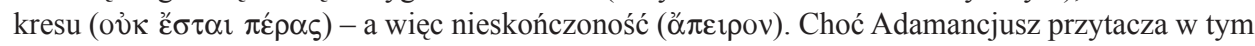
miejscu wypowiedź psalmisty, to jest ona według niego natury teologicznej, a więc wyraża prawdę o tym, jakim w rzeczywistości Bóg jest. W ekonomii zbawienia natomiast, Bóg jawi się nie takim jakim jest, lecz takim jakim nie jest, a mianowicie w sposób skończony. Myśli, mówi, a niekiedy nawet wygląda i działa jak człowiek, na co wskazują liczne biblijne antropomorfizmy. Szerzej na temat rozróżnienia na teologię i ekonomię zob. D. Mrugalski, Bóg niezdolny do gniewu. Obrona apathei Boga w teologii aleksandryjskiej: Filon, Klemens i Orygenes, VV 33 (2018) [w druku].

${ }^{61}$ Por. Mrugalski, Nieskończoność Boga u Orygenesa, s. 462-466. 


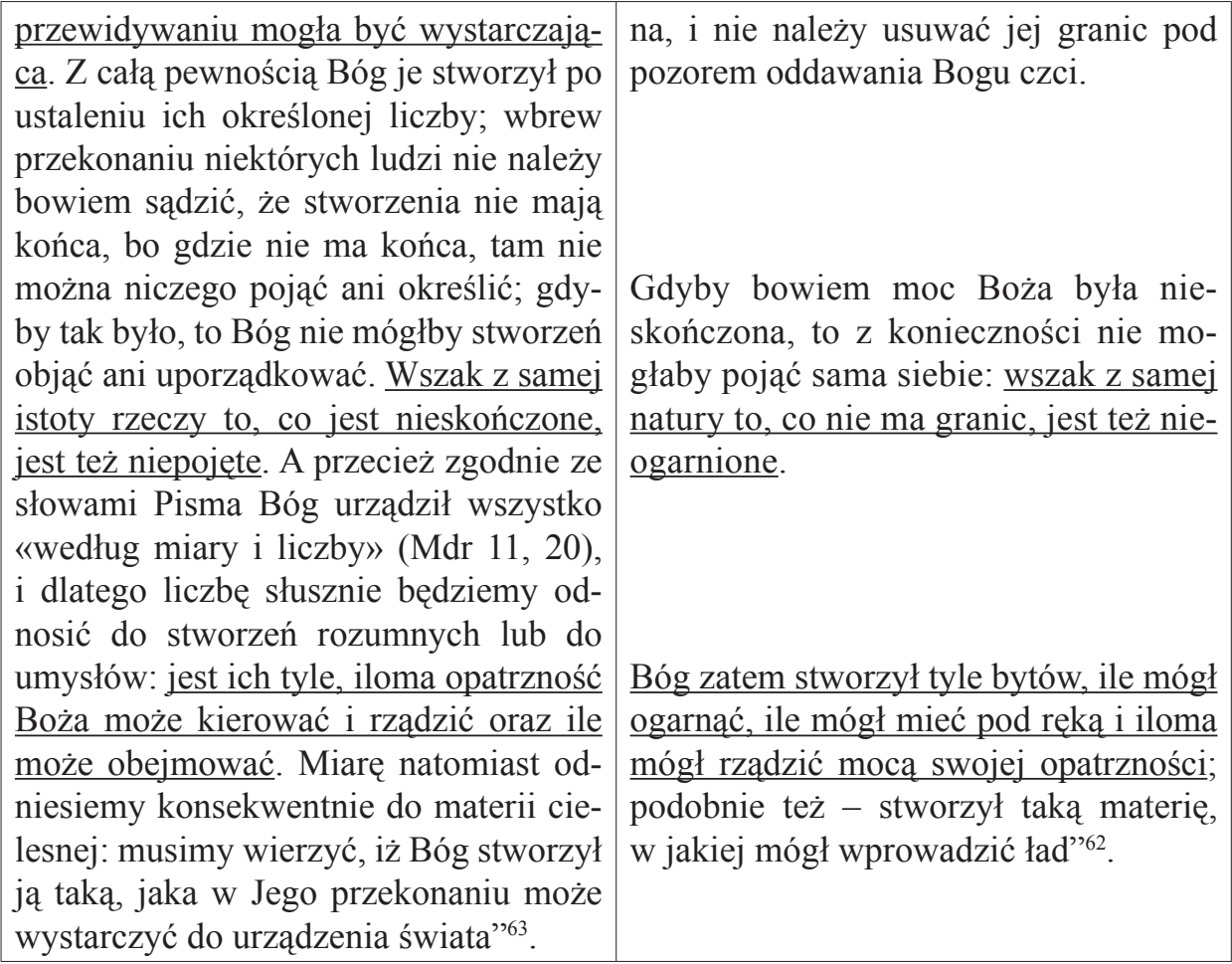

Pierwszy wniosek jaki nasuwa się przy porównywaniu obu fragmentów dotyczy ich objętości. Łacińskie thumaczenie Rufina jest obszerniejsze w sto-

${ }^{62}$ Justinianus Imperator, Epistula ad Mennam Constantinopolitanum, Mansi IX 489= Origenes,

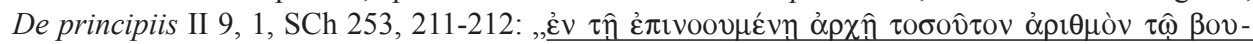

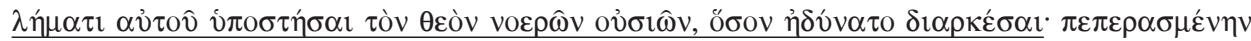

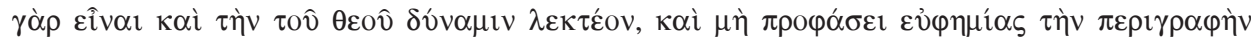

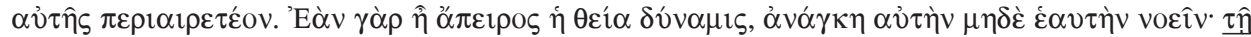

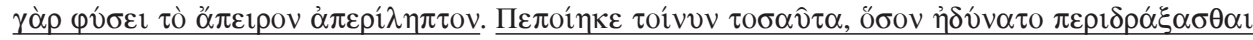

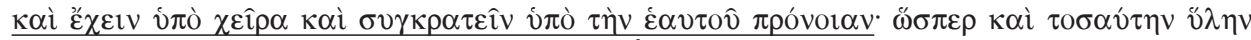

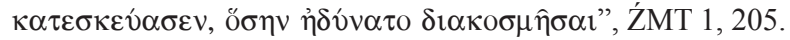

${ }^{63}$ Origenes, De principiis II 9, 1, SCh 252, 352-354: „In illo ergo initio putandum est tantum numerum rationabilium creaturarum uel intellectualium, uel quoquomodo appellandae sunt quas mentes superius diximus, fecisse deum, quantum sufficere posse prospexit. Certum est enim quod praedefinito aliquo apud se numero eas fecit; non enim, ut quidam uolunt, finem putandum est non habere creaturas, quia ubi finis non est, nec conpraehensio ulla uel circumscriptio esse potest. Quodsi fuerit, utique nec contineri uel dispensari a deo quae facta sunt poterunt. Naturaliter nempe quidquid infinitum fuerit, et inconpraehensibile erit. Porro autem sicut et scriptura dicit, numero et mensura uniuersa condidit deus, et idcirco numerus quidem recte aptabitur rationabilibus creaturis uel mentibus, ut tantae sint, quantae a prouidentia dei et dispensari et regi et contineri possint. Mensura uero materiae corporali consequenter aptabitur; quam utique tantam a deo creatam esse credendum est, quantam sibi sciret ad ornatum mundi posse sufficere”, ŹMT 1, 191. 
sunku do fragmentu przytoczonego przez Justyniana. Należy zauważyć, że długość tekstu łacińskiego nie jest jedynie wynikiem użycia bardziej rozbudowanych sformułowań w porównaniu $\mathrm{z}$ fragmentem po grecku, lecz jest rezultatem pojawienia się dodatkowych wypowiedzi zawierających idee, których nie znajdujemy $\mathrm{w}$ tekście cesarza. Z drugiej strony, w krótszym fragmencie Justyniana zawarte są stwierdzenia, których nie posiada tekst Rufina. Nie można stąd jednakże wyprowadzać wniosku, że tłumacz łaciński usunął kontrowersyjne wypowiedzi Orygenesa i dodatkowo uzupełnił jego argumentację albo że cesarz tendencyjnie przypisał obce myślicielowi z Aleksandrii idee i dopisał własną argumentację do prawdziwych tez Adamancjusza.

Podkreślone przeze mnie zdania (choć nie w każdym przypadku tekst łaciński jest wiernym odpowiednikiem tekstu greckiego) zawierają wspólne dla obu fragmentów idee. Możemy więc być pewni, że rzeczywiście stanowią one prawdziwy pogląd Orygenesa. Tak więc, według myśliciela z Aleksandrii:

1. Na początku Bóg stworzył taką ilość bytów rozumowych, jaka była wy-

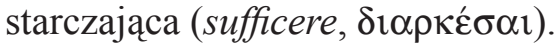

2. Z natury rzeczy wynika, że nieskończoność (infinitum, ő $\pi \varepsilon \iota \rho o v)$ jest nieobejmowalna (inconpraehensibile, ỏ $\pi \varepsilon \rho^{\prime} \lambda \eta \pi \tau o v$ ).

3. Bytów stworzonych jest tyle, iloma Boża opatrzność jest w stanie kie-

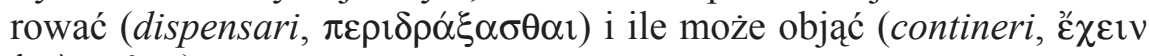
ĩò̀ $\chi \varepsilon \hat{\imath} \rho \alpha)$.

Wszystkie powyższe tezy są zgodne z nauką wypływającą z Pisma, a mianowicie, że Bóg stworzył skończony świat (por. Mdr 11,20) oraz z logiką Arystotelesa, a mianowicie, że nieskończoność jest nieobejmowalna. Choć w przytoczonych fragmentach nie ma o tym mowy, na podstawie analiz przeprowadzonych w poprzednim paragrafie, można by dodać, że Bóg działając ad extra, a więc także gdy stwarza świat, posługuje się jedynie pewnym zakresem swej absolutnej mocy. Gdyby bowiem w akcie stwórczym posłużył się całą swoją moca (potentia Dei absoluta), musiałby stworzyć drugi absolut, którego, ze względu na nieskończoność jego natury, nie mógłby objąć. Tak wyrażoną tezę znajdujemy w traktacie De Trinitate Nowacjana, który wypowiada explicite to, czego w powyższym fragmencie Orygenes nie dopowiedział:

„Nie może być dwóch bytów nieskończonych, jak dyktuje sama natura rzeczy (nec duo infinita esse possunt, ut rerum dictat ipsa natura). Nieskończonym natomiast jest coś, co nie ma w ogóle ani początku, ani końca. A coś, co ma w posiadaniu całość, rzeczywiście wyklucza istnienie innego nieskończonego. Dlatego też [Bóg], jeśli nie obejmuje (continet) wszystkiego, co jest czymkolwiek to jest - przestanie być Bogiem. Będąc bowiem we wnętrzu tego, przez którego jest obejmowany (continetur), okazuje się mniejszym od tego, przez którego jest obejmowany" ${ }^{94}$.

${ }^{64}$ Novatianus, De Trinitate 4, 8-9, ed. G.F. Diercks, CCL 4, Turnholti 1972, 18, thum. własne. 
Nie jest tu miejsce, aby zajmować się kwestią, czy Nowacjan mógł znać traktat Orygenesa $\mathrm{i}$ go w jakiś sposób cytować ${ }^{65}$ (choć powyższy fragment może na to wskazywać ze względu na bliskość występowania terminów: infinitum, rerum natura, contineo pojawiających się również w thumaczeniu Rufina). Wystarczy zauważyć, że jego rozumowanie odpowiada temu, o czym myślał, ale czego nie wyraził wprost Adamancjusz. Skończoność stworzenia nie wynika bowiem jedynie z danych skrypturystycznych, lecz z natury rzeczy (to znaczy z logiki). Gdyby świat był nieskończony, Bóg nie mógłby być Bogiem, gdyż nie mógłby go objąć i nim rządzić. Z natury rzeczy bowiem nieskończoność jest nieobejmowalna.

Wróćmy teraz do fragmentu przekazanego nam przez cesarza Justyniana. Tezy, które pojawiają się w nim, a nie występują w thumaczeniu łacińskim, są następujące:

1. Moc Boża jest ograniczona ( $\pi \varepsilon \pi \varepsilon \rho \alpha \sigma \mu \varepsilon \dot{v} \eta)$.

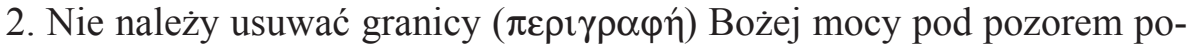
bożności.

3. Moc Boża musi być skończona, gdyż w przeciwnym razie nie mogłaby

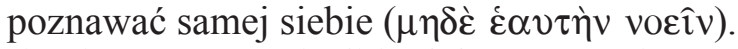

Dwie pierwsze tezy, jeśli je dobrze rozumieć, mogłyby wyrażać prawdziwy pogląd Orygenesa. Otóż zgodnie z tym, co już zostało wyżej powiedziane, moc Boża stwarzająca świat została w pewien sposób ograniczona $(\pi \varepsilon \pi \varepsilon \rho \alpha-$ $\sigma \mu \varepsilon ́ v \eta)$. Kosmos bowiem stworzyła, jest w nim obecna i działa potentia Dei ordinata. Nie należy usuwać jej granicy ( $\pi \varepsilon \rho \imath \gamma \rho \alpha \varphi \eta ́)$, pod pozorem pobożności, gdyż stworzenie uczestniczy jedynie w pewnym zakresie ( $\mu \varepsilon ́ \tau \rho o v)$ mocy, która w sposób absolutny ( $\propto$ đó $\lambda v \tau o v$ ) istnieje tylko w Bogu. Jest ona w stanie uczynić wszystko, z wyjątkiem zła. Może więc stworzyć o wiele więcej niż to, co zostało stworzone według zaplanowanej przez Boga miary. Mówienie o potentia Dei ordinata nie sprzeciwia się więc istnieniu potentia Dei absoluta, o której Adamancjusz wspomina w wielu miejscach swoich dzieł. Jeśli zaś chodzi o ostatnią spośród wyliczonych wyżej tez, choć może ona budzić pewne wątpliwości, ze względu na to, że Orygenes wprost stwierdza, że Bóg poznaje samego siebie, to również możemy ją uznać za Orygeniańską, wziąwszy

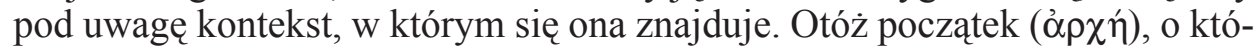
rym mówi powyższy tekst, jest związany z Bożą Mądrością. To w Niej ( $\dot{\varepsilon} v$

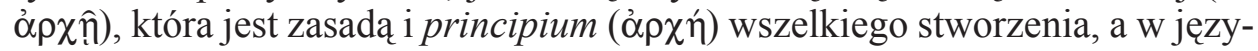

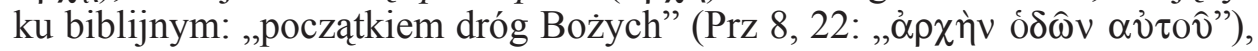
Bóg stworzył świat bytów rozumnych ${ }^{66}$. Niezależnie od tego, czy uznamy, że owe byty są jedynie ideami Bożej mądrości, czy też realnie subsystującymi bytami duchowymi, ich liczba musiała być skończona, gdyż w przeciwnym razie sama Mądrość (vel Moc) nie mogłaby ogarnąć tego, co w Niej istnieje.

${ }^{65}$ Szerzej na ten temat zob. Mrugalski, Nieskończoność Boga u Nowacjana, s. 147-181.

${ }^{66}$ Por. Origenes, De principiis I 2, 2-3; I 4, 3-4; tenże, Commentarius in Joannem I 19, 113-115; I 34, 243-244; II 18, 126; tenże, In Genesim homiliae 1, 1. 


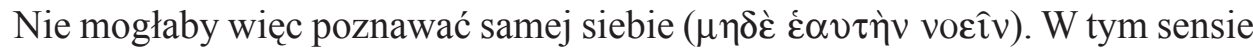
mamy tu do czynienia nadal z potentia Dei ordinata, gdyż Orygenes, kiedy mówi o świecie, nie ogranicza go jedynie do sumy bytów cielesnych istniejących na Ziemi, lecz w ogóle odnosi się do całego uniwersum bytów widzialnych i niewidzialnych - do wszystkiego, co od Boga bierze swój początek, a co Bogiem nie jest ${ }^{67}$.

Pozostaje jednak jeszcze ostatnie stwierdzenie, dotyczące materii, które jest podobne $\mathrm{w}$ obu fragmentach, choć $\mathrm{w}$ obu nacisk położony jest na inna kwestię. Otóż zarówno w tekście Justyniana, jak i w thumaczeniu Rufina, jest mowa o stworzeniu materii. Orygenes wyznaje bowiem doktrynę creatio ex nihilo, o czym zresztą mówi wprost w innym miejscu ${ }^{68}$. We fragmencie Rufina zostaje podkreślona „miara”, którą należy odnosić do stworzonej materii (w domyśle: a nie do Boga). We fragmencie Justyniana natomiast zostaje podkreślone to, że Bóg stworzył taką (albo: tyle) materię, jaką (albo: ile) był

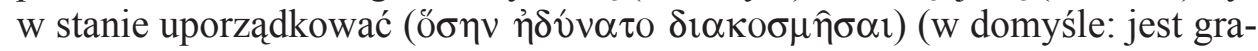
nica zdolności stwórczych Boga). W tym przypadku, nie będę wydawał oceny o większej lub mniejszej wiarygodności obu stwierdzeń. Jednemu i drugiemu można bowiem zarzucić pewną tendencyjność nakierowaną na obronę bądź podważenie ortodoksyjności Orygenesa. Niemniej jednak to, co zostaje wypowiedziane wprost w obu wersjach, to fakt stworzenia i skończoności materii.

Drugi fragment, w którym jest mowa o skończonej mocy Boga, choć nadal jedynie w przekazie Justyniana, jest następujący:

\begin{tabular}{|c|c|}
\hline Tłumaczenie De principiis Rufina & Fragment De principiis u Justyniana \\
\hline $\begin{array}{l}\text { „A uczynił wszystko w liczbie i mierze; } \\
\text { nic bowiem nie jest dla Boga bez końca } \\
\text { albo bez miary. }\end{array}$ & $\begin{array}{l}\text { „Niechaj zaś nikt się nie oburza, że rów- } \\
\text { nież mocy Bożej przypisujemy miare. } \\
\text { Natura bowiem nie może objąć nieskoń- } \\
\text { czoności. A jeśli raz zostało określone } \\
\text { to, co Bóg ogarnia, z konieczności nale- } \\
\text { ży zakreślić granicę we wszystkich rze- } \\
\text { czach określonych"69. }\end{array}$ \\
\hline
\end{tabular}

${ }^{67}$ Por. tamże. We wszystkich wyliczonych w powyższym przypisie fragmentach jest mowa o różnicy zachodzącej między Bogiem a stworzeniem. Choć na początku Bóg stworzył wszystko w swojej Mądrości (lub w Logosie, lub nawet - jak w Homiliach do Księgi Rodzaju - w Zbawicielu), to różnica między Bogiem a stworzeniem jest taka, że to ostatnie od Boga pochodzi, z Niego czerpie swe istnienie i w Nim ma swój początek.

${ }^{68}$ Por. tenże, Commentarius in Joannem I 17, 103.

${ }^{69}$ Justinianus Imperator, Epistula ad Mennam Constantinopolitanum, Mansi IX 525 = Orige-

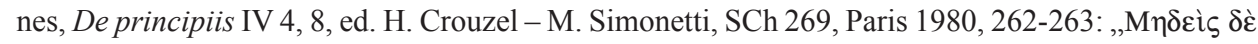

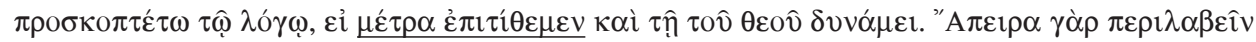

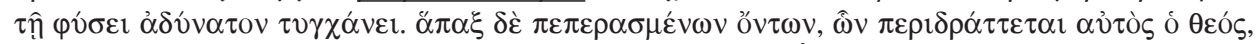

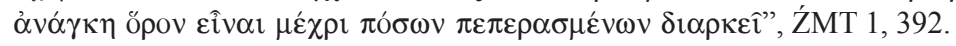




\begin{tabular}{|c|c|}
\hline $\begin{array}{l}\text { Albowiem mocą swoją obejmuje wszyst- } \\
\text { ko, a sam nie został objęty umysłem żad- } \\
\text { nego stworzenia. }\end{array}$ & $\begin{array}{l}\text { „Jeśli zaś Ojciec obejmuje wszystko, } \\
\text { a między wszystkim jest Syn, to jasne, } \\
\text { że obejmuje również Syna. Ktoś inny } \\
\text { zapyta, czy prawdą jest, że Bóg pozna- } \\
\text { je samego siebie w podobny sposób, } \\
\text { jak jest poznawany przez Jednorodzo- } \\
\text { nego i okaże się, że zupełną prawda jest } \\
\text { stwierdzenie: «Ojciec, który mnie po- } \\
\text { słał, jest większy ode mnie» (J 14, 28), to } \\
\text { znaczy, że i w zakresie poznania Ojciec } \\
\text { jest większy, a więc poznaje siebie wy- } \\
\text { raźniej i dokładniej, niźli jest poznawany } \\
\text { przez Syna"70. }\end{array}$ \\
\hline $\begin{array}{l}\text { Natura ta jest bowiem znana tylko so- } \\
\text { bie samej. Bo tylko Ojciec zna Syna } \\
\text { i tylko Syn zna Ojca, a tylko «Duch } \\
\text { Święty przenika nawet głębokości } \\
\text { Boże» (1Kor } 2,10) \text {. Całe więc stwo- } \\
\text { rzenie jest u Niego rozdzielone w pew- } \\
\text { nej liczbie i mierze, to znaczy albo } \\
\text { w liczbie istot rozumnych, albo w mie- } \\
\text { rze materii cielesnej"71. }\end{array}$ & \\
\hline
\end{tabular}

Jak nie trudno zauważyć, oprócz stwierdzenia, że „Bóg obejmuje wszystko”, oraz że wszystko dla Boga „ma miarę”, na co wskazują podkreślone przeze mnie sformułowania, nie wiele łączy obie przekazane nam wersje tekstu. W konsekwencji, dziwić może fakt, że Paul Koetschau, autor edycji krytycznej dzieła De principiis, włączył fragment Justyniana do tekstu głównego ${ }^{72}$, zamiast umieścić go w przypisach lub w komentarzu, jak to uczynili Crouzel i Simonetti. W rzeczywistości bowiem, wariant Justyniana kończy się stwierdzeniem,

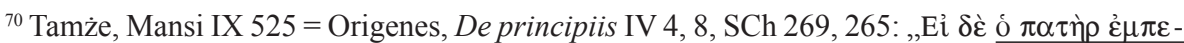

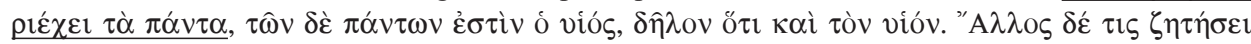

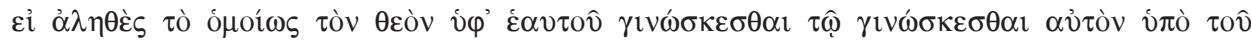

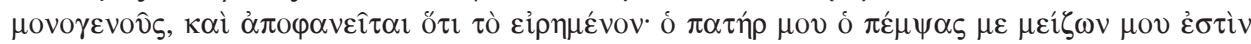
$\dot{\varepsilon} v \pi \hat{\alpha} \sigma \mathrm{iv} \alpha \dot{\alpha} \lambda \eta \theta \dot{\varepsilon} \varsigma$.

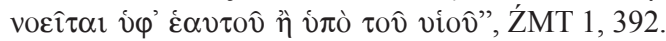

${ }^{71}$ Origenes, De principiis IV 4, 8, SCh 268, 420: „Fecit autem omnia numero et mensura; nihil enim deo uel sine fine uel sine mensura est. Uirtute enim sua omnia conpraehendit, et ipse nullius creaturae sensu compraehensus est. Illa enim natura soli sibi cognita est. Solus enim pater nouit filium, et solus filius nouit patrem, et solus «spiritus sanctus perscrutatur etiam alta dei». Omnis igitur creatura intra certum apud eum numerum mensuramque distinguitur, id est uel rationabilium numerum uel mensuram materiae corporalis", ŹMT 1, 387.

${ }^{72}$ Por. Origenes Werke, vol. 5: De principiis, ed. P. Koetschau, GCS 22, Leipzig 1913, 359-360. 
że Syn nie posiada pełnej wiedzy o Ojcu, po czym, w wydaniu Koetschau'a, następuje passus thumaczenia Rufina, w którym jest mowa o tym, że tylko Syn zna Ojca - dwie tezy zaprzeczające sobie nawzajem. O tym, że w tym przypadku tekst przekazany przez Rufina wydaje się być bardziej wiarygodny, świadczy inna wypowiedź Orygenesa pochodząca z dzieła zachowanego w języku greckim:

„Jeśli zaś ktoś zapyta, czy nasz Zbawiciel wie wszystko, co zna Ojciec dzięki swej «głębokości bogactw, mądrości i wiedzy» (Rz 11, 33), i jeśli pod pozorem oddawania chwały Ojcu, i pomimo tego, że Syn ma wiedzę równą wiedzy niezrodzonego Ojca, twierdzić będzie ten ktoś, iż Syn nie zna czegoś, co wiadome jest Ojcu, to w takim przypadku trzeba utwierdzić się w przeświadczeniu, że Zbawiciel jest Prawda, zdając sobie jednocześnie sprawę, że jeśli jest pełną prawdą, to zna wszystko, co jest prawdziwe. Rzecz w tym, by wątła prawda nie potykała się w tym, czego nie zna, i co, wedle jego opinii, związane jest wyłącznie z Ojcem. I niech ktoś spróbuje dowieść, że istnieją rzeczy, które można poznać, a których nie obejmuje zakres terminu «prawda», lecz są ponad nią"’33.

Syn więc będąc Prawdą w sensie absolutnym, jest wszystkim tym, co wie Ojciec i dlatego nie można powiedzieć, że Ojciec zna coś, czego nie znałby Syn. Ponadto, w innym zachowanym w języku greckim fragmencie Komentarza do Ewangelii Jana Orygenes stwierdza, że podczas gdy ludzie poznaja

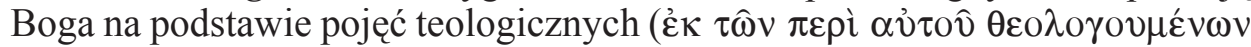
$\dot{\varepsilon} v$ vot $\hat{\omega} v)$, „On sam posiada wiedzę o sobie samym, nie na podstawie takich

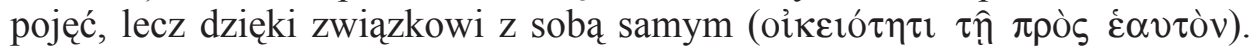

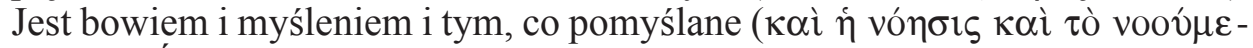
vov)" "'74. Ścisły związek między myśleniem Boga i tym, co pomyślane, to według Orygenesa relacja między Ojcem i Synem. Dlatego też Aleksandryjczyk dodaje zaraz: „Tylko Syn, będąc myślany przez Ojca, ma wiedzę o Ojcu, my-

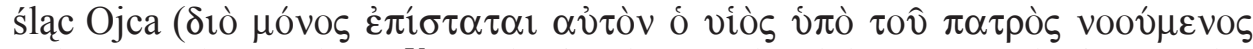

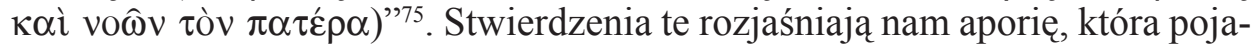
wia się w obu fragmentach Justyniana, a która jest z pewnością aporią samego cesarza, nie Orygenesa. Jest ona następująca: skoro stworzenie jest skończone, gdyż inaczej Bóg nie mógłby go objąć i poznawać, to również Bóg musi być skończony, gdyż w przeciwnym razie nie mógłby poznać samego siebie, albo też Syn, będąc obejmowany przez Ojca, a więc będąc skończony, nie może znać Ojca w zupełności. Adamancjusz jednak, będąc świadom konsekwencji wypowiadanych przez siebie tez, wskazuje na dwa różne sposoby poznawania. Człowiek poznaje przez pojęcia, a pojęcie, jest czymś, co może być obję-

\footnotetext{
${ }^{73}$ Origenes, Commentarius in Joannem I 27, 187, SCh 120, 152-154, ŹMT 27, 61.

${ }^{74}$ Tenże, Commentarius in Joannem, fr. 51, ed. E. Preuschen, GCS 10, Leipzig 1903, 495, tłum własne.

${ }^{75}$ Tamże.
} 
te przez intelekt. Bóg natomiast poznaje siebie bez pośrednictwa pojęć. Tylko On będąc myśleniem i tym, co pomyślane może znać siebie nie będąc przez to zamknięty przez żadne pojęcie. Może więc poznawać, to znaczy przenikać nieskończoną głębię swojej mądrości i wiedzy, gdyż tylko w Jego przypadku myślenie utożsamia się z tym, co pomyślane, a zarazem stanowi o Jego istocie ${ }^{76}$.

Wydaje się więc, że Justynian połączył zagadnienie mocy, którą jest Syn, z zagadnieniem transcendencji ontologicznej Ojca względem Syna (odrębna kwestia) ${ }^{77}$, a także z zagadnieniem wiedzy Syna o Ojcu (jeszcze inna kwestia). Każda z nich może być i jest rozpatrywana przez Orygenesa na różnym poziomie. Może on więc mówić o skończonej mocy Boga (potenia Dei ordinata), jak i o mocy nieskończonej w Bogu (potentia Dei absoluta). Może też rozpatrywać Ojca jako transcendentnego względem Syna, gdyż istotnie Ojciec jest źródłem wszelkiego istnienia, a zarazem mówić o równości w naturze i Bóstwie Ojca i Syna. Może w końcu mówić, że Syn jest obejmowany przez Ojca, gdyż istotnie Ojciec myśli Syna, a Syn jest tym, co jest pomyślane przez Ojca, a zarazem nie wykluczać absolutnej wiedzy Syna na temat Ojca w związku $\mathrm{z}$ identycznością natur i wzajemnym przenikaniem $\mathrm{sie}^{78}$.

${ }^{76}$ Szerzej na ten temat poznawania Ojca przez Syna zob. R.D. Williams, The Son's Knowledge of the Father in Origen, w: Origeniana Quarta, ed. L. Lies, Innsbruck - Wien 1987, 146-153.

${ }^{77}$ Szerzej na ten temat zob. S. Fernández, Verso la teologia trinitaria di Origene: Metafora e linguaggio teologico, w: Origeniana Decima: Origen as Writer. Papers of the 10th International Origen Congress, University School of Philosophy and Education "Ignatianum", Kraków, Poland 31 August - 4 September 2009, ed. S. Kaczmarek - H. Pietras - A. Dziadowiec, Leuven - Paris - Walpole, 2011, 457-473. Zob. także Mrugalski, Metamorfozy platońskiej , metafory stońca”, s. 45-53.

${ }^{78} \mathrm{O}$ tym, iż Justynian mógł w tym miejscu tendencyjnie połączyć wiele autentycznych tez Orygenesa świadczy również analogiczny fragment przekazany przez Hieronima, który różni się zarówno od tego, co przekazał Rufin, jak i cesarz. Zob. Hieronymus, Epistula 124, 13 = Origenes, De principiis IV 4, 8, SCh 269, 263, ŹMT 1, 392: „Jeśli bowiem Syn zna (cognoscit) Ojca, to zdaje się, że przez to, iż zna (nouit) Ojca, może Go obejmować (conprehendere) - tak jakbyśmy powiedzieli, że duch artysty zna miarę sztuki. Nie ulega wątpliwości, że jeśli Ojciec jest w Synu, to jest obejmowany (conprehendatur) przez Tego, w którym jest. Jeśli zaś mówimy o takim obejmowaniu (conprehensionem), że ktoś nie tylko umysłem i mądrością obejmuje (conprehendat), lecz mocą i potęgą trzyma wszystko, co poznał (cuncta teneat quae cognouit), to nie możemy mówić, że Syn obejmuje (conprehendat) Ojca. Ojciec zaś obejmuje wszystko (omnia conprehendit); między wszystkim jest też i Syn, a zatem obejmuje i Syna (filium conprehendit)". Choć Hieronim we wprowadzeniu do tego fragmentu mówi o bluźnierstwie Orygenesa, to przedstawione w nim rozumowanie wyraźnie rozróżnia dwa podejścia do omawianego zagadnienia: ontologiczne i epistemologiczne, z którymi związany jest czasownik conprehendo („obejmować”, ,pojmować”). Z punktu widzenia epistemologicznego, Syn obejmuje (conprehendit) Ojca umysłem, czyli poznaje i zna (cognoscit / nouit) Ojca. Z punktu widzenia ontologicznego, Syn pochodząc od Ojca, jest przez Niego obejmowany (conprehendatur), gdyż jest mocą Ojca. Nie można więc powiedzieć, że Syn swą mocą i potęgą trzyma czy obejmuje (teneat / conprehendit) Ojca. W dalszej części tego Hieronimowego przekazu (zob. tamże, SCh 269, 264, ŹMT 1, 392) pojawia się wprawdzie wypowiedź podobna do tej, którą znajdujemy u Justyniana, a mianowicie, że „również w zakresie poznania Ojciec jest większy od Syna, skoro doskonalej i wyraźniej jest poznawany przez siebie samego niźli przez Syna”, jest jednak ona postawiona w formie pytania, które może zadać uważny czytelnik (curiosus lector inquirat utrum...). 
Po tych wyjaśnieniach możemy stwierdzić, że zdanie, które pojawia się w wyżej zacytowanym fragmencie Justyniana: „Niechaj zaś nikt się nie oburza, że również mocy Bożej przypisujemy miarę" mogło rzeczywiście wyjść spod pióra Orygenesa. Istotnie, moc Boża stwarzająca świat posiada miarę. Poprzez akt stwórczy Bóg bowiem nie uczynił „drugiego siebie”. Użył takiej miary swej absolutnej i nieskończonej mocy, jakiej chciał. Dalsze rozważania Justyniana natomiast, które dotyczą już wiedzy Syna o Ojcu, nie tylko zaprzeczają temu, co pojawia się w thumaczeniu Rufina, ale także temu, co Orygenes explicite wyjaśnił w innych swoich dziełach zachowanych w języku greckim. Końcowa wypowiedź zacytowanego fragmentu Listu do Manesa, wydaje się więc być kompilacją wyrwanych z kontekstu różnych konceptów Orygeniańskich, których dokonał sam cesarz.

Zaznaczmy na koniec, że wielu badaczy ${ }^{79}$ nadal podejmuje próby udzielenia odpowiedzi na pytanie, na ile Rufin, tłumacz De principiis, poprawiał kontrowersyjne wypowiedzi Orygenesa, kiedy i dlaczego omijał trudniejsze passusy oraz na ile wiarygodne są fragmenty przekazane przez Hieronima i Justyniana, którzy ze swej strony starali się zaostrzać pewne stwierdzenia

Nie zostaje jednak udzielona odpowiedź samego Orygenesa na tak postawioną kwestię. To, co w przekazie Hieronima jest jedynie pytaniem, we fragmencie Justyniana staje się kategorycznym stwierdzeniem. Zob. także H. Crouzel - M. Simonetti, w: SCh 253, 265-266, nota 64. Według tych badaczy fragment przekazany przez Hieronima jest kontynuacją wypowiedzi zawartej u Rufina: „Albowiem mocą swoją obejmuje wszystko, a sam nie został objęty umysłem żadnego stworzenia”. Moim zdaniem jest to wielce prawdopodobne. Dodałbym jednakże, że dalsza wypowiedź przekazana przez Rufina, zaczynająca się od słów: „Natura ta jest bowiem znana tylko sobie samej. Bo tylko Ojciec zna Syna i tylko Syn zna Ojca, a tylko «Duch Święty przenika nawet głębokości Boże»”, może z kolei być kontynuacją fragmentu przekazanego przez Hieronima (a pominiętego przez Rufina). Stanowi ona wszakże odpowiedź na zadane w końcowej części Hieronimowego fragmentu pytanie: „czy również w zakresie poznania Ojciec jest większy od Syna”. „Uważnemu czytelnikowi” (curiosus lector) zostaje więc udzielona odpowiedź następująca: choć rzeczywiście Syn, pochodząc od Ojca, jest przez niego obejmowany (kwestia ontologiczna), to jednak ze względu na jedność Bożej natury i na inny niż ludzki sposób poznawania Boga, Syn i Duch znają Ojca (kwestia epistemologiczna). Owo poznanie polega na przenikaniu nieskończonych „głębokości Bożych”, które może dokonać tylko ktoś, kto posiada Boską naturę.

${ }^{79}$ Oprócz artykułu Samuela Fernándeza, o którym mowa w następnym przypisie, kwestia interwencji Rufina w łacińskich tłumaczeniach dzieł Orygenesa została podjęta w następujących publikacjach: N. Pace, Ricerche sulla traduzione di Rufino del «De principiis» di Origene, Firenze 1990; H. Crouzel, Les prologues de Rufin à ses traductions d'Origene, w: Esegesi e Storia in Rufino di Concordia, ed. Centro di antichità altoadriatiche, Udine 1992, 109-120; G. Sfameni Gasparro, Aspetti della controversia origeniana: le traduzioni latine del «Peri Archon», w: Origene e la tradizione origeniana in Occidente. Letture storico-religiose, ed. G. Sfameni Gasparro, Roma 1998, 13-26; C. Noce, Some Questions about Rufinus' Translation of Origen's «Homiliae in Leviticum», StPatr 43 (2006) 451-458; J. Żelazny, Rufinowa koncepcja roli i zadań tlumacza, PS 10 (2006) nr 19, 337-346; A. Grappone, Omelie origeniane nella traduzione di Rufino. Un confronto con i testi greci, SEA 103, Roma 2007; K.D. Hill, Rufinus as an Interpreter of Origen: Ascetic Affliction in the "Commentarii in Epistulam ad Romanos», „Augustiniana” 60 (2010) 145-168; C.M. Chin, Rufinus of Aquileia and Alexandrian Afterlives. Translation as Origenism, JECS 18 (2010) 617-647. 
i oddawać jako kategoryczne to, co było tylko hipotetyczne. Jednym z takich badaczy jest Samuel Fernández, który uznał, że analizowane wyżej dwa fragmenty z De principiis II 9, 1 oraz IV 4, 8 są jednym z przykładów świadomego pominięcia, lub poprawienia kontrowersyjnej wypowiedzi Orygenesa ${ }^{80}$. Ten sam autor jednakże w konkluzji swoich badań dotyczących ingerencji Rufina stwierdza, że „całościowe studium aspektu doktrynalnego De principiis wymagałoby spojrzenia na całość dzieła Orygenesa, na każdy pojedynczy punkt doktryny przez niego rozważany" "81, co jest oczywiście ogromnym przedsięwzięciem, któremu mogłaby być poświęcona niejedna monografia. W niniejszym artykule skupiliśmy się jedynie na zagadnieniu Bożej mocy odwołując się - właśnie jak sugeruje Fernández - do innych miejsc dzieła Orygenesa, w których rozważany jest ten temat. U końca naszych rozważań, zmuszeni jesteśmy przyznać, że nie jesteśmy w stanie stwierdzić jednoznacznie, czy to Rufin świadomie pominął tekst o skończonej mocy Boga, a zastąpił go stwierdzeniem o skończoności stworzeń, czy też Justynian zaostrzył wypowiedź Orygenesa w tej kwestii i dopisał kategoryczne konkluzje. Jakkolwiek by było, obie wersje, Rufina i Justyniana, zakładając interpretację, którą wyłożyliśmy powyżej, mogą odpowiadać poszczególnym elementom bardzo wyrafinowanej i subtelnej spekulacji mistrza z Aleksandrii.

Pobieżna analiza (a właściwie jej brak) dwóch greckich fragmentów dzieła De principiis, w których pojawia się explicite stwierdzenie o skończonej mocy Boga, doprowadziła wielu badaczy do wniosku, że Orygenes zachował greckie, negatywne rozumienie nieskończoności, to znaczy jako czegoś niedoskonałego. Do przekazu Justyniana (gdyż od niego pochodzą oba fragmenty) można jednak podchodzić w dwojaki sposób. Można uznać, że wiernie zreferował on wypowiedź myśliciela z Aleksandrii, którą w swym thumaczeniu poprawił Rufin broniący ortodoksyjności mistrza, albo też uznać ją za tendencyjna, a tym samym przyznać rację thumaczowi, który w tym przypadku dobrze oddał myśl wyrażoną w De principiis. W poprzednich swoich badaniach starałem się dowieść, że prawdziwa jest druga z tych opinii, którą znajdujemy także w tekstach, zachowanych w języku greckim, w których Adamancjusz posługuje się terminem ő́ $\pi \varepsilon ı \rho \circ \varsigma \mathrm{w}$ odniesieniu do Boga. Przemawia za nią także kontynuacja wielu konceptów teoretycznych poprzedników Orygenesa - Filona i Klemensa z Aleksandrii, którą nietrudno dostrzec we wszystkich jego dziełach. W niniejszym tekście jednak założyłem na wstępie, że stwier-

${ }^{80}$ Por. S. Fernández, Gli interventi dottrinali di Rufino nel De Principiis di Origene, w: L'Oriente in Occidente. L'Opera di Rufino di Concordia. Atti del Convegno Internazionale promosso dalla Facoltà Teologica del Triveneto e dal Gruppo Italiano di Ricerca su Origene e la Tradizione Alessandrina (Portogruaro, 6-7 dicembre 2013), ed. M. Girolami, Brescia 2014, 34-37.

${ }^{81}$ Tamże, s. 41, tłum. własne. 
dzenia, które zawierają dwa fragmenty przekazane przez Justyniana, rzeczywiście mogły wyjść spod pióra Orygenesa i postanowiłem zbadać, w jaki inny (niż przyjmuje to większość badaczy) sposób można je interpretować.

Do osiagnięcia tego celu posłużyła mi analiza tekstów, w których pojawia się dystynkcja na moc Boga in se i moc Boga ad extra, która była obecna w myśli aleksandryjskiej przynajmniej od czasów Filona. Ten właśnie myśliciel żydowski, broniąc radykalnej transcendencji Boga, a zarazem polemizując z filozofami greckimi, którzy zarzucali Bogu bezczynność, mówił o nieskończonych mocach Boga udzielającego się światu. Posługiwał się przy tej okazji metaforą słońca i promieni słonecznych, aby wyjaśnić, w jaki sposób transcendentny i niemający styku z materią Bóg może powodować zmiany i oddziaływać na ziemską rzeczywistość. Podobnie więc jak owe promienie, choć oświecają i ogrzewają ziemię, nie posiadają na niej takiej samej mocy, jak tę, którą mają u swego źródła - to jest w słońcu - tak też jest i z mocami Boga. Te ostatnie, choć są natury inteligibilnej (a więc nie o ograniczenie ciepła czy światła tu chodzi), również musiały zostać w odpowiedni sposób odmierzone, aby mogło je przyjąć skończone stworzenie. Moc Boga ze swej natury jest więc nieskończona, działając w świecie jednak zostaje w pewien sposób dopasowana stosownie do możliwości przyjmujących ją stworzeń. Można więc powiedzieć, że w świecie obecny jest pewien skończony zakres nieskończonej mocy Boga.

Orygenes natomiast, już nie tylko rozróżnia na moc istniejącą w Bogu i tę działającą w świecie, którą w obu przypadkach jest Jego Syn - Moc i Mądrość Boża - lecz także dotyka tematu, którym zajmą się myśliciele średniowieczni w związku z debatą dotyczącą rozróżnienia na potentia Dei absoluta i potentia Dei ordinata. Zastanawia się bowiem, czy Bóg może uczynić wszystko, również to, czego nie uczynił i odpowiada: tak - może, z wyjątkiem zła. Zło natomiast, będąc niebytem nie ogranicza w żaden sposób Bożej wszechmocy. Moc absolutna Boga, która jest nieskończona, z woli samego Boga zostaje jednak ograniczona. Dzieje się to wówczas, kiedy Bóg stwarza świat lub kiedy w nim działa. Teza ta jest zgodna z nauką Pisma, na które powołuje się Orygenes, ale i logiką Arystotelesa. Jeśli bowiem nieskończoności z natury objąć nie można, to gdyby świat był nieskończony, Bóg nie mógłby objać tego, co sam stworzył, albo też gdyby Bóg stwarzając świat posłużył się całą swoją absolutną mocą, musiałby stworzyć drugi równy sobie nieskończony Absolut. Logika jednak nie pozwala na istnienie obok siebie dwóch nieskończoności.

Posługując się dystynkcją na potentia Dei absoluta i potentia Dei ordinata, nie uważam bym narzucał późniejszy, średniowieczny koncept do tworzącej się dopiero teologii. Do dostrzeżenia tego rozróżnienia doprowadziła mnie analiza samych tekstów Adamancjusza, który posługując się terminami:

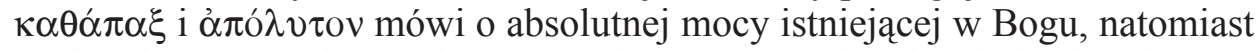

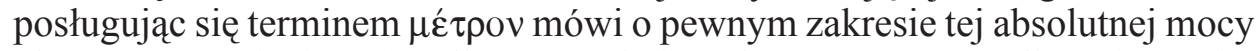
obecnym w świecie. Nie tylko moc, ale i mądrość Boga są według niego nie- 
skończone i bezgraniczne. Stworzenie natomiast po części i na różny sposób uczestniczy w tym, czego pełnia jest w transcendentnym Bogu. Świadczą o tym liczne teksty pochodzące z dzieł egzegetycznych Orygenesa, na które się powoływałem, a w których jest mowa o nieskończonych głębinach, myślach, śladach, wyrokach czy drogach Bożej mądrości i mocy. Nie może ich prześledzić i pojąć żaden ludzki intelekt, gdyż nieskończoność ze swej natury nie może być objęta przez coś skończonego.

Rozróżnienie na potentia Dei absoluta i potentia Dei ordinata rzuca nowe światło na zachowane u Justyniana fragmenty z De principiis. Tak jak założyłem we wstępie, wypowiedź o tym, że „moc Boża jest ograniczona, i nie należy usuwać jej granic pod pozorem oddawania Bogu czci”, można uznać za autentyczną. W takiej lub podobnej formie mogła się więc ona pojawić w oryginale wspomnianego dzieła Orygenesa. Istotnie bowiem moc Boga stwarzającego świat posiada granice - jest bowiem odpowiednio wymierzona czy uporządkowana. Tych granic nie wyznacza Bogu nic zewnętrznego, gdyż jak to wielokrotnie podkreśla Adamancjusz, nic nie jest w stanie ograniczyć nieustannie udzielającego się Dobra - Dobra samego ( $\alpha v \tau o \alpha \gamma \alpha \theta$ ó $)$ ), którym jest Bóg. To On sam wyznacza wszelkie granice, wszelką „miarę i liczbę” temu, co stwarza. Sam też odpowiednio udziela swej mocy dostosowując ją do możliwości przyjmujących ją stworzeń.

Podobnie rzecz ma się z drugim zachowanym u Justyniana fragmentem, który nie wiele różni się od pierwszego, choć znacznie odbiega od analogicznej wypowiedzi zachowanej w łacińskim tłumaczeniu Rufina, jak i tej, którą przekazał Hieronim. Kwestią dodana jest w tym przypadku stwierdzenie o tym, że w zakresie poznania Ojciec jest większy od Syna, gdyż obejmuje Syna, sam nie będąc przez nic objęty. Wykazałem jednak, również na podstawie zachowanych w języku greckim fragmentów innych dzieł Orygenesa, że uzasadnienie, które znajdujemy w drugim analizowanym fragmencie Justyniana jest kompilacją różnych, autentycznych, choć wyrwanych z kontekstu, tez Adamancjusza. Jedne bowiem dotyczą ontologii, inne epistemologii. Łączy je jednak czasownik conprehendo, który może oznaczać zarówno obejmowanie, jak i pojmowanie. Syn więc, z punktu widzenia ontologicznego jest obejmowany przez Ojca, gdyż od Niego pochodzi oraz jest tym, co myśli Ojciec. W tym sensie nie można powiedzieć, że Syn obejmuje Ojca, gdyż Ojciec nie pochodzi od Syna. Syn jednak zna Ojca ze względu na wspólną z Nim Boską naturę i tylko On wraz z Duchem Świętym są w stanie przenikać nieskończone „głębokości bogactw, mądrości i wiedzy Boga”. Co zaś się tyczy przekazanej przez cesarza wypowiedzi - „Niechaj zaś nikt się nie oburza, że również mocy Bożej przypisujemy miarę", - nie mam wątpliwości, że należy ją uznać za autentycznie Orygeniańską.

Konkludując, możemy stwierdzić, że dwa fragmenty dzieła De principiis, które zawiera List do Manesa cesarza Justyniana, zanalizowane tu w świetle rozróżnienia na potentia Dei absoluta i potentia Dei ordinata, zawierają 
liczne koncepty, o których dowiadujemy się z innych, zachowanych w języku greckim dzieł mistrza z Aleksandrii. Choć, według Orygenesa, absolutna moc Boga jest nieskończona, to jednak uporządkowana moc Boga stwarzającego świat posiada pewne granice, które On sam wyznaczył.

\section{POTENTIA DEI ABSOLUTA ET POTENTIA DEI ORDINATA IN ORIGEN? A NEW ATTEMPT TO EXPLAIN THE CONTROVERSIAL FRAGMENTS OF DE PRINCIPIIS}

\section{(Summary)}

The medieval dispute over the absolute and the ordered, power of God (potentia Dei absoluta et potentia Dei ordinata) began with a tract by Peter Damian entitled De divina omnipotentia. One of the questions posed in this work was whether God could indeed do everything, including those things that God did not in fact do. The same question, and a similar answer, appears in Origen's work Contra Celsum: God can do everything except that which is evil. The impossibility of doing evil, however, does not diminish the omnipotence of God, because evil, is by its very nature, non-being. Beyond that, Origen, in numerous statements appearing in his exegetical works, distinguishes between the absolute power of God, which is infinite, and the power of God that creates the world and operates within it, which has a certain God-given limit - that is, this power is adapted to the abilities of the creatures who receive it. The purpose of this article is to show that, in the light of the distinction of the potentia Dei absoluta and the potentia Dei ordinata, fragments of De principiis (II 9.1 and IV 4.8), in which a finite world and finite power of God are posited, can be interpreted in a new way. Many contemporary scholars, on the basis of these fragments, conclude that Origen inherited from the Greek philosophers a negative understanding of infinity as something imperfect, but the analysis carried out in this article shows something different. In talking about a certain range of God's power, which is available to creatures, or in which creatures participate only partially, Origen does not actually exclude the proposition that, in God himself, power - existing in an absolute way - can be infinite.

Key words: Origen, power of God, potentia Dei absoluta, potentia Dei ordinata, infinity of God, transcendence of God, unknowability of God, wisdom of God, Philo of Alexandria, patristic philosophy, philosophical influences on Christian doctrine.

Słowa kluczowe: Orygenes, moc Boga, potentia Dei absoluta, potentia Dei ordinata, nieskończoność Boga, transcendencja Boga, niepoznawalność Boga, mądrość Boga, Filon z Aleksandrii, filozofia patrystyczna, wpływy filozoficzne na doktrynę chrześcijańską. 


\section{BIBLIOGRAFIA}

\section{Źródła}

Aristoteles, Physica, ed. I. Bekker: Aristotelis opera edidit Academia Regia Borussica, vol. 1, Berlin 1831, tłum. K. Leśniak: Arystoteles, Zachęta do filozofii. Fizyka, Warszawa 2010.

Concilium Chalcedonense (451), Definitio fidei, tekst grecko-łacińsko-polski, układ i oprac. A. Baron - H. Pietras, thum. T. Wnetrzak, ŹMT 24 = DSP 1, Kraków 2001, 214-225.

Hieronymus, Epistulae, ed. I. Hilberg, CSEL 54, Vienna 1996, CSEL 55, Vienna 1996, CSEL 56/1, Vienna 1996, tłum. J. Czuj: Hieronim, Listy, t. 1-5, opr. M. Ożóg, red. H. Pietras, ŹMT 54, Kraków 2010, ŹMT 55, Kraków 2010, ŹMT 61, Kraków 2011, ŹMT 63, Kraków 2011, ŹMT 68, Kraków 2013.

Justinianus ImPerator, Epistula ad Mennam Constantinopolitanum, Mansi IX 487-534.

Novatianus, De Trinitate, ed. G.F. Diercks, CCL 4, Turnholti 1972, 11-78, tłum. G. Jaśkiewicz: Nowacjan, O Trójcy Świętej, ŹMT 35, Kraków 2005.

Origenes, Commentariorum in Matthaeum series, ed. E. Klostermann, GCS 38, Leipzig 1933, thum. K. Augustyniak: Orygenes: Komentarz do Ewangelii wedtug św. Mateusza (Część druga: Commentarium series), ŹMT 25, Kraków 2002.

Origenes, Commentarius in Epistulam ad Romanos, ed. L. Brésard - M. Fédou, SCh 532, Paris 2009, SCh 539, Paris 2010, SCh 543, Paris 2011, SCh 555, Paris 2012, thum. S. Kalinkowski: Orygenes, Komentarz do Listu św. Pawła do Rzymian, PSP 57, Warszawa 1994.

Origenes, Commentarius in Joannem, ed. C. Blanc, SCh 120, Paris 1966, SCh 157, Paris 1970, SCh 222, Paris 1975, SCh 290, Paris 1982, SCh 385, Paris 1992, thum. S. Kalinkowski: Orygenes, Komentarz do Ewangelii wedlug św. Jana, ŹMT 27, Kraków 2003, 25-562.

Origenes, Commentarius in Joannem: Fragmenta, ed. E. Preuschen, GCS 10, Leipzig 1903, tłum. S. Kalinkowski: Orygenes, Fragmenty o Ewangelii św. Jana, ŹMT 27, Kraków 2003, 563-641.

Origenes, Commentarius in Matthaeum, XII-XVII, ed. E. Klostermann, GCS 40, Leipzig 1935, X-XI, ed. R. Girod, SCh 162, Paris 1970, tłum. K. Augustyniak: Orygenes, Komentarz do Ewangelii wedtug św. Mateusza, ŹMT 10, Kraków 1998.

Origenes, Contra Celsum, ed. M. Borret, SCh 132, Paris 1967, SCh 136, Paris 1968, SCh 147, Paris 1969, SCh 150, Paris 1969, thum. S. Kalinkowski: Orygenes, Przeciw Celsusowi, Warszawa 1986.

Origenes, De oratione, ed. P. Koetschau, GCS 3, Leipzig 1899, 295-403, tłum. W. Kania H. Pietras: Orygenes, O modlitwie, w: Odpowiedź na Słowo, red. H. Pietras, Kraków 1993, 101-240.

Origenes, De principiis, ed. H. Crouzel, M. Simonetti, SCh 252, Paris 1978, SCh 253, Paris 1978, SCh 268, Paris 1980, SCh 269, Paris 1980, tłum. S. Kalinkowski: Orygenes, O zasadach, ŹMT 1, Kraków 1996.

Origenes, In Genesim homiliae, ed. H. de Lubac - L. Doutreleau, SCh 7bis, Paris 2003, tłum. S. Kalinkowski: Orygenes, Homilie o Księdze Rodzaju, PSP 31/1, Warszawa $1985,155-278$.

Origenes, In Ieremiam homiliae, ed. P. Nautin - P. Husson, SCh 238, Paris 1977, thum. S. Kalinkowski, Orygenes, Homilie o Księdze Jeremiasza. Komentarz do Lamentacji Jeremiasza. Homilie o Księgach Samuela i Księgach Królewskich, PSP 30, Warszawa 1983, 23-211. 
Origenes, In Numeros homiliae, ed. L. Doutreleau, SCh 415, Paris 1996, SCh 442, Paris 1999, SCh 461, Paris 2001, tłum. S. Kalinkowski: Orygenes, Homilie o Księdze Liczb, ŹMT 76, Kraków 2016.

Origenes, In Psalmos homiliae, GCSNF 19, ed. L. Perrone - M. Molin Pradel - E. Prinzivalli - A. Cacciari, Berlin - München - Boston 2015.

Origenes, Philocalia, 21-27, ed. É. Junod, SCh 226, Paris 1976, tłum. K. Augustyniak: Orygenes, Filokalia, Warszawa 1979.

Origenes, Selecta in Psalmos, PG 12, 1053-1686.

Petrus Damianus, De divina omnipotentia, ed. A. Cantin, SCh 191, Paris 1972, tłum. M. Gensler: Piotr Damiani, O Boskiej wszechmocy. Rozprawa o tym, w jaki sposób Bóg, jeśli jest wszechmogacy, może sprawić, żeby to, co się stało, się nie stato, w: Antologia tekstów filozoficznych i teologicznych z III-XI wieku, red. E. Jung, Kraków 2012, 247-278.

Philo Alexandrinus, Opera, ed. G.P. Goold, w: Philo in Ten Volumes, t. 1: LCL 226, Cambridge - London 1981, t. 2: LCL 227, Cambridge - London 1994, t. 3: LCL 247, Cambridge - London 1988, t. 4: LCL 261, Cambridge - London 1985 t. 5: LCL 275, Cambridge - London 1988, t. 6: LCL 289, Cambridge - London 1984, t. 7: LCL 320, Cambridge - London 1998, t. 8: LCL 341, Cambridge - London 1999, t. 9: LCL 363, Cambridge - London 1985, t. 10: LCL 379, Cambridge - London 1991, thum. L. Joachimowicz: Filon Aleksandryjski, Pisma, t. 1, Warszawa 1986, thum. S. Kalinkowski, Pisma, t. 2, Kraków 1994.

\section{Opracowania}

Barnes M.R., The Power of God: $\Delta$ v́vauı in Gregory of Nyssa's Trinitarian Theology, Washington 2001.

Beeley C.A., The Unity of Christ: Continuity and Conflict in Patristic Tradition, New Haven - London 2012.

Brink G. VAn DEN, Almighty God: A Study of the Doctrine of Divine Omnipotence, Kampen 1993.

Bucur B.G., The Early Christian Reception of Genesis 18: From Theophany to Trinitarian Symbolism, JECS 23 (2015) 245-272.

Chin C.M., Rufinus of Aquileia and Alexandrian Afterlives. Translation as Origenism, JECS 18 (2010) 617-647.

Courtenay W.J., Capacity and Volition: A History of the Distinction of Absolute and Ordained Power, Bergamo 1990.

Crouzel H., Les prologues de Rufin à ses traductions d'Origene, w: Esegesi e Storia in Rufino di Concordia, ed. Centro di antichità altoadriatiche, Udine 1992, 109-120.

Decharneux B.S., Divine Powers in Philo of Alexandria's ,, De opificio mundi”, w: Divine Powers in Late Antiquity, ed. A. Marmodoro - I.F. Viltanioti, Oxford 2017, 127-139.

Edwards M., The Power of God in Some Early Christian Texts, w: Divine Powers in Late Antiquity, ed. A. Marmodoro - I.F. Viltanioti, Oxford 2017, 163-176.

Fernández S., Gli interventi dottrinali di Rufino nel De Principiis di Origene, w: L'Oriente in Occidente. L'Opera di Rufino di Concordia. Atti del Convegno Internazionale promosso dalla Facoltà Teologica del Triveneto e dal Gruppo Italiano di Ricerca su Origene e la Tradizione Alessandrina (Portogruaro, 6-7 dicembre 2013), ed. M. Girolami, Brescia 2014, 27-44.

FERnÁndez S., Verso la teologia trinitaria di Origene: Metafora e linguaggio teologico, w: Origeniana Decima: Origen as Writer. Papers of the 10th International Origen Congress, University School of Philosophy and Education "Ignatianum", Kraków, 
Poland 31 August - 4 September 2009, ed. S. Kaczmarek - H. Pietras - A. Dziadowiec, Leuven - Paris - Walpole, 2011, 457-473.

GraPPONE A., Omelie origeniane nella traduzione di Rufino. Un confronto con i testi greci, SEA 103, Roma 2007.

HeIne R.E., Epinoiai, w: The Westminster Handbook to Origen, ed. J.A. McGuckin, Louisville - London 2004, 93-95.

HiLl K.D., Rufinus as an Interpreter of Origen: Ascetic Affliction in the "Commentarii in Epistulam ad Romanos», „Augustiniana” 60 (2010) 145-168.

Jung E., Świat możliwy versus świat realny w koncepcjach średniowiecznych, czyli o boskiej mocy absoluta i ordinata, ,Filo-Sofija” 30 (2015) 67-80.

Kalinkowski S., Pneumatologia Orygenesa, CT 53 (1983) 43-56.

Moreschini C., Storia della filosofia patristica, Brescia 2005.

Mrugalski D., Bóg niezdolny do gniewu. Obrona apathei Boga w teologii aleksandryjskiej: Filon, Klemens i Orygenes, VV 33 (2018) [w druku].

Mrugalski D., Metamorfozy platońskiej „,metafory stońca” (Respublica 509b) w hetero- $i$ ortodoksyjnej teologii (I-III w.): Gnostycyzm, Klemens z Aleksandrii i Orygenes, VoxP 37 (2017) t. 68, 21-58.

Mrugalski D., Nieskończoność Boga u Nowacjana: Prawdopodobne źródta greckie, „Przegląd Tomistyczny” 23 (2017) 147-181.

Mrugalski D., Nieskończoność Boga u Orygenesa: Przyczyna wielkiego nieporozumienia, VoxP 37 (2017) t. 67, 437-475.

Noce C., Some Questions about Rufinus'Translation of Origen's «Homiliae in Leviticum», StPatr 43 (2006) 451-458.

Pace N., Ricerche sulla traduzione di Rufino del «De principiis» di Origene, Firenze 1990.

Paluch M., Jak zdefiniować wszechmoc? Wprowadzenie do Kwestii I, w: Tomasz z Akwinu, Kwestie dyskutowane o mocy Boga, t. 1, red. M. Olszewski - M. Paluch, Kęty - Warszawa 2008, 19-52.

Paluch M., Oswajanie wszechmocy. Droga do Tomaszowej interpretacji wszechmocy, „Przegląd Tomistyczny” 15 (2009) 263-279.

Pazzini D., Figlio, w: Origene. Dizionario. La cultura, il pensiero, le opere, a cura di A. Monaci Castagno, Roma 2000, 161-168.

Pepliński M., Problematyka wszechmocy Boga - rzeczy nowe i stare, „Filo-Sofija” 30 (2015) 11-44.

Ramelli I.L.E., Divine Power in Origen of Alexandria: Sources and Aftermath, w: Divine Powers in Late Antiquity, ed. A. Marmodoro - I.F. Viltanioti, Oxford 2017, 177-198.

Sfameni Gasparro G., Aspetti della controversia origeniana: le traduzioni latine del «Peri Archon», w: Origene e la tradizione origeniana in Occidente. Letture storico-religiose, ed. G. Sfameni Gasparro, Roma 1998, 13-26.

Simonetti M., Dio (Padre), w: Origene. Dizionario. La cultura, il pensiero, le opere, ed. A. Monaci Castagno, Roma 2000, 118-124.

Szram M., Chrystus - Madrość Boża wedtug Orygenesa, Lublin 1997.

SzRam M., Orygenes, PEF VIII 860-869.

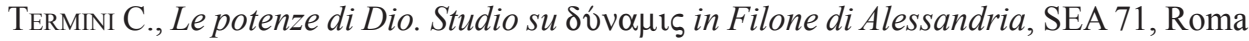
2000.

Tzamalikos P., Origen: Philosophy of History \& Eschatology, Leiden 2007.

Williams R.D., The Son's Knowledge of the Father in Origen, w: Origeniana Quarta, ed. L. Lies, Innsbruck - Wien 1987, 146-153.

ŻELAZNY J., Rufinowa koncepcja roli i zadań tłumacza, PS 10 (2006) nr 19, 337-346. 